\title{
Origin and evolution of formation waters, Alberta Basin, Western Canada Sedimentary Basin. II. Isotope systematics and water mixing
}

\author{
Cathy A. Connolly \\ Department of Geology, The University of Alberta, Edmonton, Alberta T6G 2E3, Canada \\ LYNN M. WALTER \\ Department of Geological Sciences, The University of Michigan, Ann Arbor, MI 48109, U.S.A. \\ H. BAADSGAARD \\ Department of Geology, The University of Alberta, Edmonton, Alberta T6G 2E3, Canada \\ and \\ Fred J. Longstaffe \\ Department of Gcology, The University of Western Ontario, Biological and Geological Scicnces \\ Building, London, Ontario N6A 5B7, Canada
}

(Received 13 July 1989; accepted in revised form 12 December 1989)

\begin{abstract}
Isotopic measurements (Sr, O, D) on formation waters from the Alberta Basin have been made, covering a stratigraphic range from Devonian to Upper Cretaceous. These measurements, combined with chemical compositional trends, give evidence for two distinct water regimes. One hydrological regime is composed of waters hosted in Devonian-Lower Cretaceous reservoirs, the other waters from Upper Cretaceous and younger sedimentary rocks. The two regimes are separated by a regional transgressive shale in the Colorado Group, the Second White Speckled Shale Formation.

The waters within the Devonian-Lower Cretaceous regime exhibit a large range in ${ }^{87} \mathrm{Sr}{ }^{86} \mathrm{Sr}$ values (0.7076-0.7129), but have similar Sr concentrations, regardless of host lithology. Bulk rock and late-stage diagenetic cements are less radiogenic than present brines. Importantly, brines from Devonian carbonates possess the most radiogenic $\mathrm{Sr}$ isotopic signatures of the waters examined. Devonian shales and/or Cambrian shales may be sources of high ${ }^{87} \mathrm{Sr} /{ }^{86} \mathrm{Sr}$ ratios in the carbonate-hosted waters. Waters from the Upper Cretaceous clastic units, which have ratios as low as 0.7058 , and diagenetic cements from Upper Cretaccous clastic units appear to have precipitated from fluids similar in $\mathrm{Sr}$ isotopic value to modern brines. High $\mathrm{Sr}$ concentrations in the Cretaccous clastic waters and sedimentary rocks and correspondingly low ${ }^{87} \mathrm{Sr} /{ }^{86} \mathrm{Sr}$ ratios suggest that volcanism in Montana during the Cretaceous may have provided a source of sediments to the study area.

Cross-formational upward water migration, superimposed on lateral fluid flow, is required to explain the geochemistry and isotopic systematics in the brines from Devonian-Lower Cretaceous reservoirs. Strontium isotope ratios and $\mathrm{Sr}$ contents suggest a two component mixing relation for these waters. This system of waters also exhibits $\delta \mathrm{D}$ values characteristic of meteoric values in the Neogene, reflecting postLaramide flushing of Tertiary waters throughout the basin, with subsequent hydrochemical isolation from more modern waters. In contrast, waters in Upper Cretaceous reservoirs have $O$ and $D$ isotopic compositions similar to those of present day rainfall; these, in conjunction with very dilute $\mathrm{Sr}$ concentrations and low Sr ratios, suggest hydrological isolation from the stratigraphically lower system.
\end{abstract}

\section{INTRODUCTION}

MANY formation water studies have focused on the Western Canada Sedimentary Basin. The pioneer work establishing the character of groundwater flow in this basin is reported by HITCHON $(1969 a, b)$ and recently, further evaluation has been completed by the hydrogeological modeling of GARVEN (1985, 1989). Preliminary isotopic and chemical characteristics are reported for 78 formation waters from oil and gas fields in the basin (BILLINGs et al., 1969; Hitchon and Friedman, 1969; Hitchon et al., 1971). Although these studies provide an excellent reconnaissance of the whole Western Canada Sedimentary Basin, they do not address separate aquifer systems or intraformational variation throughout the basin.
Formation waters may originate as meteoric water recharged through and reacting with the rock column, or as connate water trapped during sediment deposition. Subsequent isotopic changes to formation waters may result from dilution by meteoric water, mixing of brines with contrasting chemical and isotopic composition, or water-rock interaction. The use of $\mathrm{Sr}$ isotopic measurements of formation waters, in conjunction with stable isotopes, can constrain the extent of water-rock interaction and clarify $\mathrm{mi}$ gration pathways. Oxygen and D values are important indicators for the origin of the water, whereas ${ }^{87} \mathrm{Sr} /{ }^{86} \mathrm{Sr}$ ratios reffect sources of dissolved $\mathrm{Sr}$ and can provide information on water mixing and migration, the extent and nature of water-rock interaction, and the chemical evolution of waters. CHaudhuri (1978) 
was the first to apply ${ }^{87} \mathrm{Sr} /{ }^{86} \mathrm{Sr}$ ratios to the investigation of oil field brines in sedimentary basins in his study of brines in central Kansas. Since then this technique has been applied to many other oilfield waters, including those in Ohio (Sunwall and PushKAR, 1979), Israel (StARINSKY et al., 1983), Arkansas (STUeber et al., 1984), Mississippi (Russel and CowART, 1985), Illinois (StUeber et al., 1987), southern Louisiana (POSEY et al., 1985) and in the Michigan and Appalachian basins (McNutT et al., 1984, 1987). No Sr isotopic analyses have yet been reported from the Alberta Basin.

The work reported here is the second of a two part study on the isotopic and chemical characteristics of a suite of oil field waters from the Alberta Basin. The purpose of this research was to determine, independent of hydrological models, the extent of interformational water mixing and the significance of waterrock interaction in a spatially restricted area of the Alberta Basin. Forty-three formation waters were sampled from different geographical locations and formations (Fig. 1). The stratigraphic and structural framework of the basin has been described in CoNNOLLY et al. (1990). Briefly, the study area is part of the Western Canada Sedimentary Basin and comprises a wedge of unfolded sedimentary rocks that thicken toward the west-southwest and rest unconformably on Precambrian basement. The wedge of sedimentary rocks is composed of thick units of: (1) Cretaceous shale and siltstone interbedded with thin lenses of sandstone; and (2) eroded Jurassic and Paleozoic carbonates, shales and evaporites. The Cretaceous clastic rocks are separated from stratigraphically lower units by a major regional unconformity. Upper Mississippian, Pennsylvanian, Permian, Triassic and most Jurassic strata are not found in the central plains of Alberta.

All of the brine samples were analyzed chemically (ConNolly et al., 1990) and for ${ }^{87} \mathrm{Sr} /{ }^{86} \mathrm{Sr}$ ratios; isotopic compositions of $\mathrm{D}$ and $\mathrm{O}$ were determined for a representative subset of brine samples. Isotopic analyses of mineral phases and rock samples from various stratigraphic units have also been determined to establish the extent of isotopic equilibration with the formation water.

\section{SAMPLE COLLECTION AND ANALYSIS}

Procedures for brine collection are described in Connolly et al. (1990). A total of 43 core samples representative of the stratigraphic units in the study area from which waters were sampled, were obtained from 14 different locations. Mineral compositions of the whole-rock and diagenetic cements were studied petrographically and by $\mathrm{X}$-ray diffraction. Whole rock samples and diagenetic cements were obtained for isotopic analyses $(\mathrm{C}, \mathrm{O}, \mathrm{Sr})$, using a slowspeed, hand-held drill.

Untreated $125 \mathrm{ml}$ aliquots of formation water for $\mathrm{O}$ and $\mathrm{D}$ analyses were collected in glass bottles filled to overflowing and capped with air-tight lids. Oxygen isotope ratios were determined by the $\mathrm{CO}_{2}$ equilibration method (EPSTEIN and
MAYEDA, 1953), but the equilibration period was extended to a week to $10 \mathrm{~d}$ to overcome kinetic effects inherent in saline brines. The equation of SoFER and GAT (1972) was used to convert the $O$ isotope analyses from activity to concentration units. The $D$ isotopic values were determined by the method of Coleman et al. (1982). Deuterium and $O$ ratios were measured by conventional gas-source mass spectrometry. Results are reported in concentration units using the usual $\delta$ notation with respect to the SMOW standard (CRAIG, 1961). The precision is $\pm 0.13 \%$ and $\pm 2.3 \%$ for $\delta^{18} \mathrm{O}$ and $\delta \mathrm{D}$, respectively.

Stable isotope analyses of carbonate minerals were obtained by reacting organic-free, powdered rock samples $(<44 \mu \mathrm{m})$ in phosphoric acid using the method of WALTERS et al. (1972), modified after McCREA (1950) and EPSTEIN et al. (1964). All $\delta^{13} \mathrm{C}$ values are given in permil notation relative to the Peedee belemnite (PDB) standard. Carbonate content and mineralogy were confirmed by XRD prior to isotope analyses; replicate isotopic analyses of carbonate minerals were better than $\pm 0.2 \%$.

A $125 \mathrm{ml}$ aliquot of formation water, acidified to $\mathrm{pH}<2$ using $\mathrm{HNO}_{3}$, was collected for determination of the ${ }^{87} \mathrm{Sr} /{ }^{86} \mathrm{Sr}$ ratios. The ${ }^{87} \mathrm{Sr} /{ }^{86} \mathrm{Sr}$ ratios in formation waters and mineral phases were measured on a VG-MM 30 mass spectrometer, following separation by standard ion exchange techniques. Dissolution of carbonate, both whole-rock and isolated diagenetic phases, was performed using ultrapure $\mathrm{HNO}_{3}$ at room temperature; dissolution of shales was accomplished using ultrapure $\mathrm{HF}$ and gentle heating. The within-run precision of a single analysis of the ratio was \pm 0.00003 ; repeated runs of the NBS-987 standard gave $0.71022( \pm 0.00005)$. The $\mathrm{Sr}$ concentration was determined by inductively coupled plasma-atomic emission spectrometry (ICP-AES); the exact conditions of analysis are described in Connoly et al. (1990).

\section{RESULTS AND DISCUSSION}

\section{General}

Sample locations, temperatures, depths and isotopic compositions of Alberta Basin formation waters are summarized in Table 1. Complete chemical analyses for these waters are reported and discussed elsewhere (ConNolly et al., 1990). In brief, the principal ionic species of Alberta Basin waters are $\mathrm{Na}$ and $\mathrm{Cl}$, with $\mathrm{Ca}$ becoming more significant in the waters from the Devonian reef strata. Although the average total dissolved solids (TDS) is relatively low $(80 \pm 47 \mathrm{~g} / \mathrm{l})$, the range in total concentration is large (4-235 g/l). Temperatures in the study area range from 35 to $75^{\circ} \mathrm{C}$ (average $=53 \pm 10^{\circ} \mathrm{C}$ ) and depths range from 680 to $1970 \mathrm{~m}$ (average $=1333 \pm 312 \mathrm{~m}$ ). The samples cover a large stratigraphic interval, but the depths and temperatures are relatively similar because of the shallow dip of the basin and availability of sample locations for specific formations. Dilute waters extend to greater depths in the western part of the basin, closer to the Canadian Cordillera, a potentiometric high.

The water samples from the Alberta Basin have been divided into three groups based on chemistry and reservoir lithology (see Fig. 1 and discussion in Connolly et al., 1990). Group I waters are from Devonian, Mississippian and lowermost Jurassic 


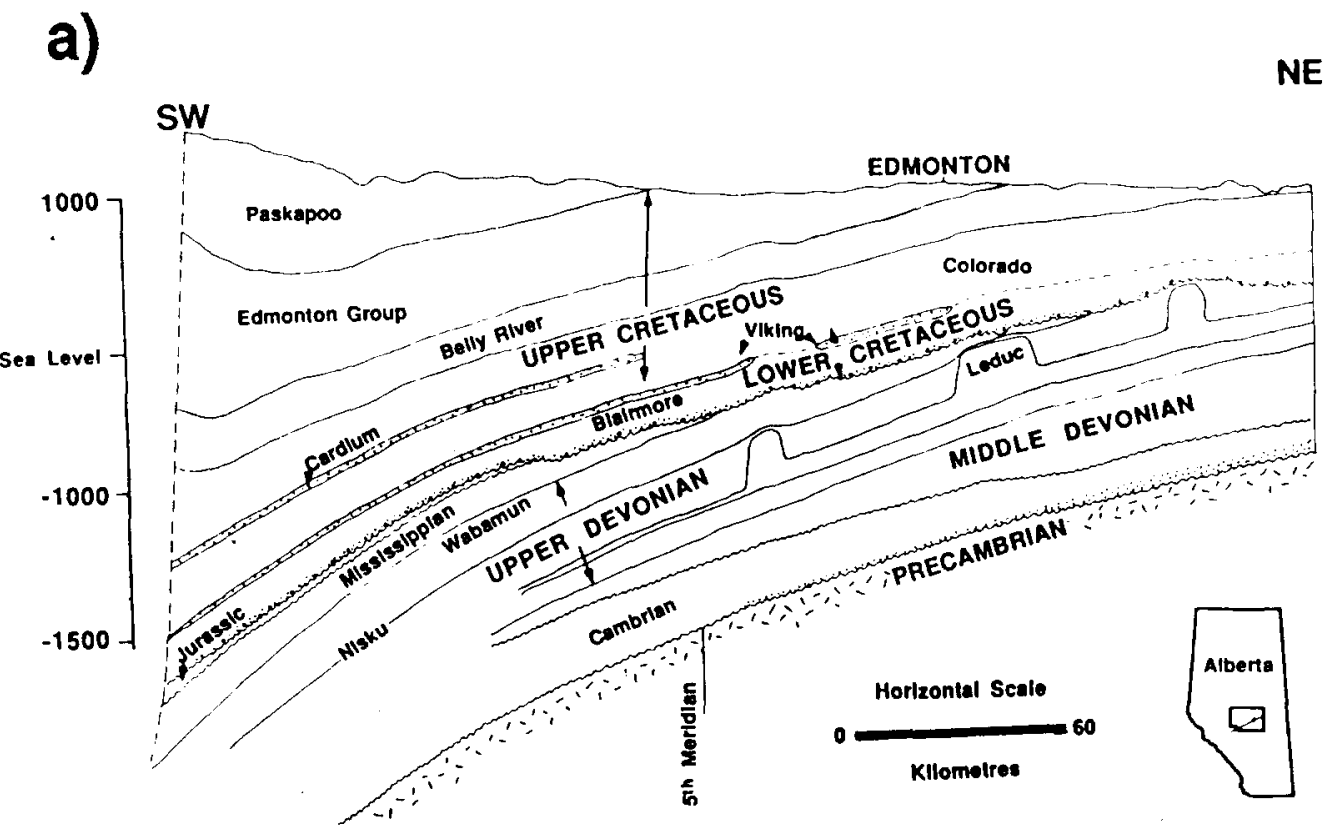

b)



FIG. 1. (a) Geological cross section from SW to NE through the Alberta Basin showing the major stratigraphic units and unconformities. The study area is highlighted in the reference map. (b) Same geological cross section as (1a) illustrating the division of the formation waters into Groups I, II and III. 
Table 1. Sample locations, depths, temperatures and isotopic compositions of Alberta Basin brines

\begin{tabular}{|c|c|c|c|c|c|c|c|c|}
\hline System & $\begin{array}{l}\text { Stratigraphic } \\
\text { unit }\end{array}$ & Location & $\begin{array}{c}\text { Depth } \\
(\mathrm{m})\end{array}$ & $\begin{array}{c}\text { Temp } \\
\left({ }^{\circ} \mathrm{C}\right)\end{array}$ & $\delta^{18} \mathrm{O}$ & $\delta \mathrm{D}$ & ${ }^{87} \mathrm{Sr} /{ }^{86} \mathrm{Sr}$ & $1 / \mathrm{Sr}$ \\
\hline \multirow[t]{7}{*}{ Upper Cretaceous } & Belly River & 6-5-49-6W5 & 1078 & 35 & -10.3 & -99 & 0.70634 & $6.03 \mathrm{E}-02$ \\
\hline & Belly River & $8-29-48-6 W 5$ & 1090 & 49 & -10.4 & -100 & 0.70628 & 4.88E-02 \\
\hline & Belly River & $2-28-48-6 W 5$ & 1076 & 45 & - & - & 0.70616 & $4.75 \mathrm{E}-02$ \\
\hline & Belly River & $16-22-47-4 W 5$ & 984 & 48 & -10.0 & -101 & 0.70578 & $6.52 \mathrm{E}-02$ \\
\hline & Cardium & $3-24-49-5 W 5$ & 1245 & 43 & 一 & - & 0.70738 & $1.53 \mathrm{E}-01$ \\
\hline & Cardium & $14-20-48-6 W 5$ & 1426 & 54 & -15.6 & -127 & 0.70890 & $9.07 \mathrm{E}-01$ \\
\hline & Cardium & $16-30-49-6 W 5$ & 1304 & 47 & -15.8 & -116 & 0.70839 & $9.62 \mathrm{E}-01$ \\
\hline \multirow[t]{15}{*}{ Lower Cretaceous } & Viking & $12-20-49-21 \mathrm{~W} 4$ & 999 & 41 & -8.0 & -83 & 0.70787 & $9.60 \mathrm{E}-03$ \\
\hline & Viking & $15-21-56-24 W 4$ & 1050 & 47 & -9.4 & -88 & 0.70768 & $5.49 \mathrm{E}-03$ \\
\hline & Viking & $8-32-55-20 W 4$ & 703 & 40 & -9.5 & -92 & 0.70852 & $4.35 \mathrm{E}-(03$ \\
\hline & Viking & $6-7-56-20 \mathrm{~W} 4$ & 676 & 44 & - & - & 0.70894 & $4.60 \mathrm{E}-03$ \\
\hline & Glauconitic & $4-36-49-4 W 5$ & 1630 & 59 & -5.5 & -82 & 0.70758 & $4.28 \mathrm{E}-03$ \\
\hline & Glauconitic & $12-16-51-4 W 5$ & 1574 & 65 & - & -82 & - & - \\
\hline & Glauconitic & $14-4-51-25 W 4$ & 1293 & - & - & - & 0.71024 & $2.78 \mathrm{E}-03$ \\
\hline & Ostracod & $16-20-49-3 W 5$ & 1609 & 65 & -6.7 & -85 & 0.70821 & $3.79 \mathrm{E}-03$ \\
\hline & Ostracod & $5-30-49-3 W 5$ & 1640 & 67 & - & -82 & 0.70859 & $6.64 \mathrm{E}-03$ \\
\hline & Basal Quartz & $10-29-56-24 \mathrm{~W} 4$ & 1067 & 46 & - & -85 & 0.70886 & $5.57 \mathrm{E}-03$ \\
\hline & Basal Quartz & $13-21-56-24 \mathrm{~W} 4$ & 1060 & - & -6.9 & -86 & 0.71008 & $5.02 \mathrm{E}-03$ \\
\hline & Basal Quartz & $14-23-52-26 \mathrm{~W} 4$ & 1253 & - & -4.6 & -118 & 0.71131 & $2.66 \mathrm{E}-03$ \\
\hline & Basal Quartz & $15-33-51-25 W 4$ & 1359 & 56 & -5.5 & -74 & 0.71137 & $2.66 \mathrm{E}-03$ \\
\hline & Basal Quartz & $2-25-52-26 \mathrm{~W} 4$ & 1237 & 52 & -5.9 & -84 & 0.71061 & $3.46 \mathrm{E}-03$ \\
\hline & Basal Quartz & $16-34-49-5 W 5$ & 1700 & 63 & - & - & 0.70945 & - \\
\hline \multirow[t]{4}{*}{ Middle Jurassic } & Rock Creck & $10-25-54-13 W 5$ & 1969 & 75 & -10.4 & -103 & 0.71220 & $3.79 \mathrm{E}-02$ \\
\hline & Rock Creek & $16-24-54-13 \mathrm{~W} 5$ & 1964 & 64 & - & - & 0.71168 & $2.66 \mathrm{E}-(02$ \\
\hline & Middle Jurassic & $8-34-49-5 W 5$ & 1699 & 57 & -4.0 & -77 & 0.70986 & $1.66 \mathrm{E}-02$ \\
\hline & Middle Jurassic & $6-34-49-5 W 5$ & 1706 & 61 & - & - & 0.70978 & $1.86 \mathrm{E}-02$ \\
\hline \multirow[t]{2}{*}{ Lower Jurassic } & Nordegg & $14-13-49-5 W 5$ & 1703 & - & -3.3 & -69 & 0.71170 & $4.18 \mathrm{E}-03$ \\
\hline & Nordegg & $1-18-52-5 W 5$ & 1647 & 67 & -4.0 & -78 & 0.71037 & $2.16 \mathrm{E}-03$ \\
\hline \multirow[t]{2}{*}{ Mississippian } & Banff & $6-31-50-4 W 5$ & 1621 & 58 & - & - & 0.71031 & $3.09 \mathrm{E}-103$ \\
\hline & Banff & $14-30-50-4 \mathrm{~W} 5$ & 1640 & 62 & -3.4 & -125 & 0.70966 & $4.81 \mathrm{E}-(03$ \\
\hline \multirow[t]{13}{*}{ Upper Devonian } & Wabamun & $9-16-57-3 W 5$ & 1340 & 50 & -5.6 & -82 & 0.71072 & $3.08 \mathrm{E}-03$ \\
\hline & Wabamun & $2-4-57-3 w 5$ & 1334 & 50 & -6.2 & -75 & 0.71062 & $2.78 \mathrm{E}-03$ \\
\hline & Wabamun & $13-20-56-3 W 5$ & 1399 & 52 & - & -73 & 0.71285 & $2.24 \mathrm{E}-03$ \\
\hline & Wabamun & $3-7-57-1 W 5$ & 1247 & 44 & -5.0 & -81 & 0.71128 & $2.55 \mathrm{E}-(03$ \\
\hline & Nisku & $15-29-49-26 \mathrm{~W} 4$ & 1596 & 69 & - & -58 & 0.71206 & $2.74 \mathrm{E}-03$ \\
\hline & Nisku & $14-3-56-24 W 4$ & 1179 & 45 & - & - & 0.70998 & $5.35 \mathrm{E}-03$ \\
\hline & Nisku & $16-10-56-24 W 4$ & 1170 & 45 & -5.3 & -77 & 0.71005 & $5.43 E-03$ \\
\hline & Leduc & $11-14-57-21 W 4$ & 972 & 41 & -5.4 & -88 & 0.70944 & $4.57 E-03$ \\
\hline & Leduc & $6-20-57-21 \mathrm{~W} 4$ & 978 & 39 & -7.2 & -82 & 0.70975 & $5.94 \mathrm{E}-013$ \\
\hline & Leduc & $7-6-58-21 \mathrm{~W} 4$ & 979 & 42 & -6.1 & -82 & 0.70937 & $5.34 \mathrm{E}-03$ \\
\hline & Leduc & $11-12-58-22 W 4$ & 985 & 42 & -4.5 & -98 & 0.70959 & $5.05 \mathrm{E}-03$ \\
\hline & Leduc & $11-15-50-26 \mathrm{~W} 4$ & 1623 & 63 & +2.4 & -104 & 0.70872 & $8.43 E-(04$ \\
\hline & Leduc & $6-23-52-26 \mathrm{~W} 4$ & 1536 & 65 & -6.8 & -87 & 0.70981 & $2.52 \mathrm{E}-03$ \\
\hline
\end{tabular}

$-=$ not analyzed

(Nordegg Formation) carbonates and the lowermost Cretaceous (Basal Quartz Formation) clastic assemblage. Group II waters are hosted by the Middle Jurassic, Ostracod, Glauconitic and Viking clastic assemblages. Group III includes waters in the clastic rocks of the Rock Creek, Cardium and Belly River stratigraphic units. Group I and Group II waters are separated from those of Group III by the Second White Speckled Shale, a regional transgressive shale. The results discussed below demonstrate that the division of waters into these three groups is suggested by the brine isotopic compositions.

\section{Oxygen and deuterium isotopes}

Basic relations. Oxygen and D isotopic analyses for the Alberta Basin formation waters are plotted in Fig. 2. Most samples from Group I and Group II have very similar $\delta \mathrm{D}$ values. Group III waters have $\delta \mathrm{D}$ values which are more negative and slope towards the meteoric water line (MWL). A least squares fit to all data intersects the meteoric water line at $\delta \mathrm{D}=$ $-121 \%_{\text {(SMOW) }}$ and $\delta^{18} \mathrm{O}=-16.3 \%_{\text {(SMOW) }}$, close to the current weighted mean annual values for present day rainfall in Edmonton, Alberta $(\delta \mathrm{D}=$ 


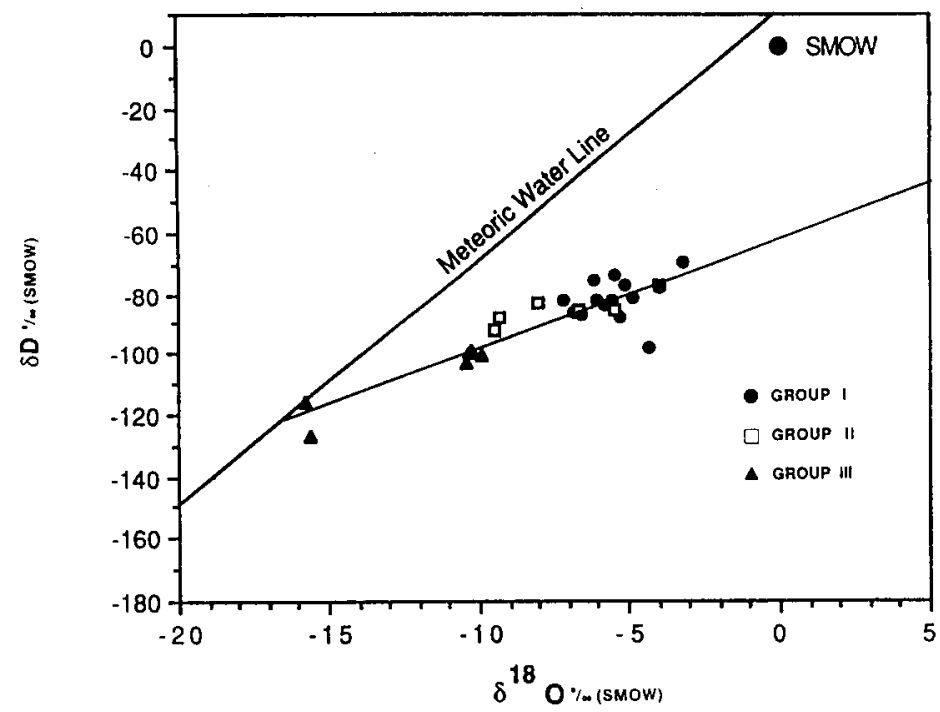

FIG. 2. Stable isotopic composition of Alberta Basin formation waters, with the Meteoric Water Line (MWL) and standard mean ocean water (SMOW) plotted for reference. All water samples plot to the right of the MWL. Intersection of the formation waters with the MWL occurs at $\delta \mathrm{D}_{(\mathrm{SMOW})}=-121 \%$ and $\delta^{18} \mathrm{O}_{\text {(SMOW })}=-16.3 \%$.

$-125 \%$ (SMOW) $_{\text {(SMO }} ; \delta^{18} \mathrm{O}=-16.3_{\text {(SMOW) }}$; DANSGAARD, 1964) (see Fig. 1 for location). Regression of the isotopic data from Hirchon and FRIEDMAN (1969), results in a meteoric water intercept of $\delta \mathrm{D}=$ $-144 \%$ (SMOW) $_{\text {(SM }}$ and $\delta \mathrm{D}^{18} \mathrm{O}=-19.3 \%_{\text {(SMOW) }}$. This is actually in reasonably good agreement with our data given that (i) the samples of HrTCHON and FrIEDMAN (1969) covered a broader geographical range than ours, and (ii) techniques for determining $\mathrm{D}$ isotopic values in saline waters have evolved and are more accurate than those in use in the 1960s (Horita and GAT, 1989).

Waters from the Jurassic Rock Creek Formation from Group III are relatively dilute and plot closer to the MWL than many stratigraphically higher samples. These samples, located in the middle of the stratigraphic section (Fig. 1), are the deepest and most westerly waters sampled (Table 1). Salinity contours increase in dip toward the west with proximity to the Canadian Cordillera (ConNolly et al., 1990). Thus, dilute, meteoric waters extend to greater depths in the western part of the Alberta Basin and the position of the Jurassic samples on Fig. 2 may be attributed to increased meteoric water influences due to the location of the reservoir from which the waters were sampled. Similar values for Jurassic waters from southern Alberta have been reported by Hitchon and Friedman (1969); however, these were attributed to meteoric recharge from the Sweetgrass Hills.

Significance of water-rock interactions. The distribution of stable isotopes in waters from the Alberta Basin can be interpreted in several ways. Simple mixing of meteoric water and ocean water will form a mixing line joining surface rain-water and SMOW (standard mean ocean water). However, the brines from the Alberta Basin fall to the right of such a line, showing a large ${ }^{18} \mathrm{O}$ enrichment relative to meteoric water, but a comparatively small enrichment in D. Water-rock interactions have often been called upon to explain the isotopic composition of waters in sedimentary basins. Albitization (LAND and PrezBINDOWSKI, 1981) and equilibration with calcite (Clayton et al., 1966; Hitchon and Friedman, 1969) can alter the $\mathrm{O}$ isotopic composition of waters, and processes such as membrane filtration can affect both $O$ and $\mathrm{H}$ isotopes (GraF et al., 1966; Kharaka et al., 1973).

Of these phenomena, $\mathrm{O}$ isotopic equilibration between the formation waters and the carbonate rocks, as a function of temperature, can be most readily tested, using the approach of CLAYTON et al. (1966). Oxygen and carbon isotopic analyses for the reservoir carbonate samples are given in Table 2 . The carbonate samples were usually obtained from the cores within $\mathrm{km}$ of the corresponding water samples.

Most of the Devonian carbonates are dolomites with the exception of the Wabamun Group, which is composed of calcite in the study area (Table 2). Although no waters could be sampled from the Middle Devonian Elk Point Group, rock samples were collected and analyzed because they lie beneath the Leduc Formation and potentially could have interacted with overlying formation waters. Diagenetic minerals were drilled out of Devonian whole-rock samples (the bulk sample) and were generally characterized by $\delta^{18} \mathrm{O}$ values similar to, but at the lower end of the range of isotopic values for whole-rock samples. In contrast to the Devonian rocks, the Jurassic and Mississippian show a pronounced discrepancy between $\delta^{18} \mathrm{O}$ values for the whole-rock samples and diagenetic calcite cements, with the 
Table 2. Isotopic compositions of Alberta Basin carbonates

\begin{tabular}{|c|c|c|c|c|c|c|c|c|}
\hline System & $\begin{array}{l}\text { Stratigraphic } \\
\text { unit }\end{array}$ & Location & $\begin{array}{l}\text { Depth } \\
\text { (m) }\end{array}$ & $\begin{array}{l}\text { Mineral } \\
\text { rock type }\end{array}$ & Type & $\delta^{13} \mathrm{C}$ & $\delta^{18} \mathrm{O}$ & ${ }^{87} \mathrm{Sr} /{ }^{86} \mathrm{Sr}$ \\
\hline \multirow[t]{7}{*}{ Upper Cretaceous } & Belly River & $8-32-48-4 W 5$ & 981 & calcite & D & 0.51 & +15.13 & 0.70604 \\
\hline & & $8-32-48-4 W 5$ & 988 & calcite & $\mathrm{D}$ & -4.71 & +12.98 & 0.70586 \\
\hline & & $8-32-48-4 W 5$ & 992 & calcite & D & -4.96 & +13.34 & 0.70590 \\
\hline & & $8-32-48-4 W 5$ & 994 & calcite & D & -5.24 & +12.53 & 0.70578 \\
\hline & & $8-32-48-4 W 5$ & 995 & calcite & $\mathrm{D}$ & -0.34 & +13.99 & 0.70615 \\
\hline & Lea Park & $8-32-48-4 W 5$ & 996 & shale & WR & - & - & 0.70745 \\
\hline & Cardium & $8-32-48-4 W 5$ & 1309 & shale & WR & - & - & 0.71938 \\
\hline \multirow[t]{15}{*}{ Lower Cretaceous } & Viking & $3-17-40-4 W 5$ & 2160 & siderite & D & -1.74 & +23.14 & 0.70776 \\
\hline & & $11-21-36-2 W 5$ & 1903 & siderite & D & -2.81 & +23.55 & - \\
\hline & & $2-30-38-7 W 5$ & 2537 & siderite & $\mathrm{D}$ & -2.13 & +21.20 & 0.70762 \\
\hline & & 13-8-35-6W5 & 2727 & siderite & D & -2.23 & +24.24 & - \\
\hline & & $16-1-46-4 W 5$ & 1734 & calcite & $\mathrm{D}$ & -7.18 & +14.09 & - \\
\hline & & $1-16-50-26 W 4$ & 1149 & calcite & $\mathrm{D}$ & 1.60 & +25.27 & - \\
\hline & & $6-16-35-5 W 5$ & 2468 & dolomite & DET & -8.50 & +22.10 & - \\
\hline & & $6-25-40-2 W 5$ & 1776 & ankerite & $\mathrm{D}$ & -2.43 & +16.30 & - \\
\hline & Glauconite & $14-12-50-26 \mathrm{~W} 4$ & 1296 & calcite & $\mathrm{D}$ & -0.44 & +18.29 & 0.71094 \\
\hline & & $4-32-48-4 W 5$ & 1758 & calcite & $\mathrm{D}$ & -2.52 & +14.90 & 0.70803 \\
\hline & & $4-32-48-4 W 5$ & 1759 & calcite & $\mathrm{D}$ & -1.72 & +15.41 & 0.70879 \\
\hline & Ostracod & $4-32-48-4 W 5$ & 1764 & calcite & $\mathrm{D}$ & -2.51 & +17.78 & 0.70865 \\
\hline & Blairmore & $1-16-50-26 \mathrm{~W} 4$ & 1338 & calcite & $\mathrm{D}$ & -1.52 & +15.05 & - \\
\hline & & $14-12-50-26 \mathrm{~W} 4$ & 1303 & shale & WR & - & - & 0.71171 \\
\hline & & $14-12-50-26 \mathrm{~W} 4$ & 1304 & calcite & $\mathrm{D}$ & -0.40 & +18.79 & - \\
\hline \multirow[t]{7}{*}{ Lower Jurassic } & Nordegg & $8-31-48-4 W 5$ & 1777 & calcite & WR & -0.73 & +20.61 & 0.70795 \\
\hline & & $8-31-48-4 W 5$ & 1780 & calcite & $\mathrm{D}$ & -1.40 & +18.77 & 0.70842 \\
\hline & & $8-31-48-4 W 5$ & 1782 & calcite & WR & -0.99 & +18.82 & 0.70892 \\
\hline & Poker Chip & $8-4-42-5 W 5$ & 2350 & shale & WR & - & - & 0.71167 \\
\hline & Jurassic & $8-32-48-4 W 5$ & 1805 & calcite & WR & -0.19 & +22.24 & 0.70844 \\
\hline & & $8-32-48-4 W 5$ & 1805 & calcite & D & -1.32 & +17.00 & 0.70874 \\
\hline & & $8-32-48-4 W 5$ & 1806 & calcite & WR & -2.99 & +19.69 & 0.70903 \\
\hline \multirow[t]{2}{*}{ Mississippian } & Banff & $4-32-48-4 W 5$ & 1776 & calcite & WR & -2.23 & +18.94 & 0.70850 \\
\hline & & $8-32-48-4 W 5$ & 1784 & calcite & WR & -1.09 & +21.19 & 0.70855 \\
\hline \multirow[t]{3}{*}{ Upper Devonian } & Wabamun & $1-16-50-26 \mathrm{~W} 4$ & 1370 & calcite & WR & -1.27 & +22.69 & 0.70902 \\
\hline & & $1-16-50-26 \mathrm{~W} 4$ & 1374 & calcite & WR & -2.93 & +18.08 & 0.70937 \\
\hline & Nisku & $1-16-50-26 \mathrm{~W} 4$ & 1554 & dolomite & WR & -2.87 & +26.68 & 0.70842 \\
\hline \multirow[t]{2}{*}{ Upper Devonian } & Leduc & $8-17-50-26 W 4$ & 1832 & dolomite & WR & 1.86 & +25.03 & 0.70830 \\
\hline & & $8-17-50-26 W 4$ & 1833 & dolomite & WR & 1.61 & +25.71 & 0.70819 \\
\hline \multirow[t]{2}{*}{ Middle Devonian } & Elk Point & $8-17-50-26 W 4$ & 2252 & dolomite & WR & 3.41 & +29.59 & 0.70922 \\
\hline & & $8-17-50-26 \mathrm{~W} 4$ & 2254 & dolomite & WR & 1.51 & +27.30 & 一 \\
\hline \multirow[t]{4}{*}{ Cambrian } & Cambrian & $8-17-50-26 W 4$ & 2635 & shale & WR & - & - & 0.74307 \\
\hline & & $8-17-50-26 W 4$ & 2638 & shale & WR & - & - & 0.77570 \\
\hline & & $8-17-50-26 W 4$ & 2643 & shale & WR & - & - & 0.75627 \\
\hline & & $8-17-50-26 W 4$ & 2645 & sst/calcite & D & - & - & 0.75038 \\
\hline \multirow[t]{2}{*}{ Precambrian } & Precambrian & $8-17-50-26 \mathrm{~W} 4$ & 2739 & greenstone & WR & - & - & 1.09317 \\
\hline & & $8-17-50-26 W 4$ & 2740 & greenstone & WR & - & - & 1.30972 \\
\hline
\end{tabular}

Abbreviations on the table are: $\mathrm{D}=$ diagenetic; $\mathrm{DET}=$ detrital; $\mathrm{WR}=$ whole-rock $;-=$ not analyzed.

cements being as much as $5 \%$ lighter for some samples.

Authigenic carbonate cements are the only carbonate phases within the clastic rocks, with the minor exception of dolomite grains in some units. Some of these rocks contain more than one generation of cement, with each generation having a distinct isoto- pic composition. For example, the Viking Formation contains siderite $\left(\delta^{18} \mathrm{O}=+18\right.$ to $+26 \%$ o(SMOW) $)$, calcite $\left(\delta^{18} \mathrm{O}=+14 \%_{\text {(SMOW })}\right)$ and ankerite $\left(\delta^{18} \mathrm{O}=\right.$ +16.3 to $+16.7 \%_{\text {(SMOW) }}$ ) cements (CoNNOLLY, in prep.) and dolomite grains $\left(\delta^{18} \mathrm{O}=+19.3\right.$ to


Many of the values reported here for the 
authigenic carbonates in the Cretaceous clastics disagree with those reported by HITCHON and FRIEDMAN (1969) for similar formations. However, their values are within the range of values reported here and the variation between the two data sets is probably because Hitchon and Friedman (1969) obtained whole-rock carbonate isotope values for sandstones without isolating cement generations.

The calcite-water fractionation factor of FRIEDMAN and O'NeIL (1977) and the dolomite-water fractionation factor of MATTHEWs and KATZ (1977) were used to calculate the $\mathrm{O}$ isotopic composition of formation water in equilibrium with calcite and dolomite, respectively, as a function of subsurface temperature. Figure $3 a-c$ shows the isotopic composition of waters in the Alberta Basin relative to the carbonate values at the present temperature of each water sample for the different water groups (I-III).

Group I waters are plotted in Fig. 3a. These waters are dominantly from carbonate reservoirs (Devonian), but also include waters from a clastic unit (Lower Cretaceous Blairmore Group). One water sample plots slightly above the Dol $26 \%$ curve, suggesting it is in equilibrium with dolomite. However, most of the waters from dolomite reservoirs are depleted in ${ }^{18} \mathrm{O}$ relative to $\mathrm{O}$ isotopic equilibrium values. In general, waters from calcitic reservoirs are also not equilibrated isotopically with the carbonate host at present temperatures, but are variably enriched or depleted in ${ }^{18} \mathrm{O}$ relative to equilibrium values. Enrichment relative to calcite likely indicates reaction with dolomitic limestone and depletion suggests remnants of the effect of the regional influx of fresh water through the basin, subsequent to the Laramide Orogeny. The waters from the clastic reservoirs in Group I (small solid dots) are enriched in ${ }^{18} \mathrm{O}$ relative to the carbonate cements present.

Waters from Group II reservoirs are dominantly
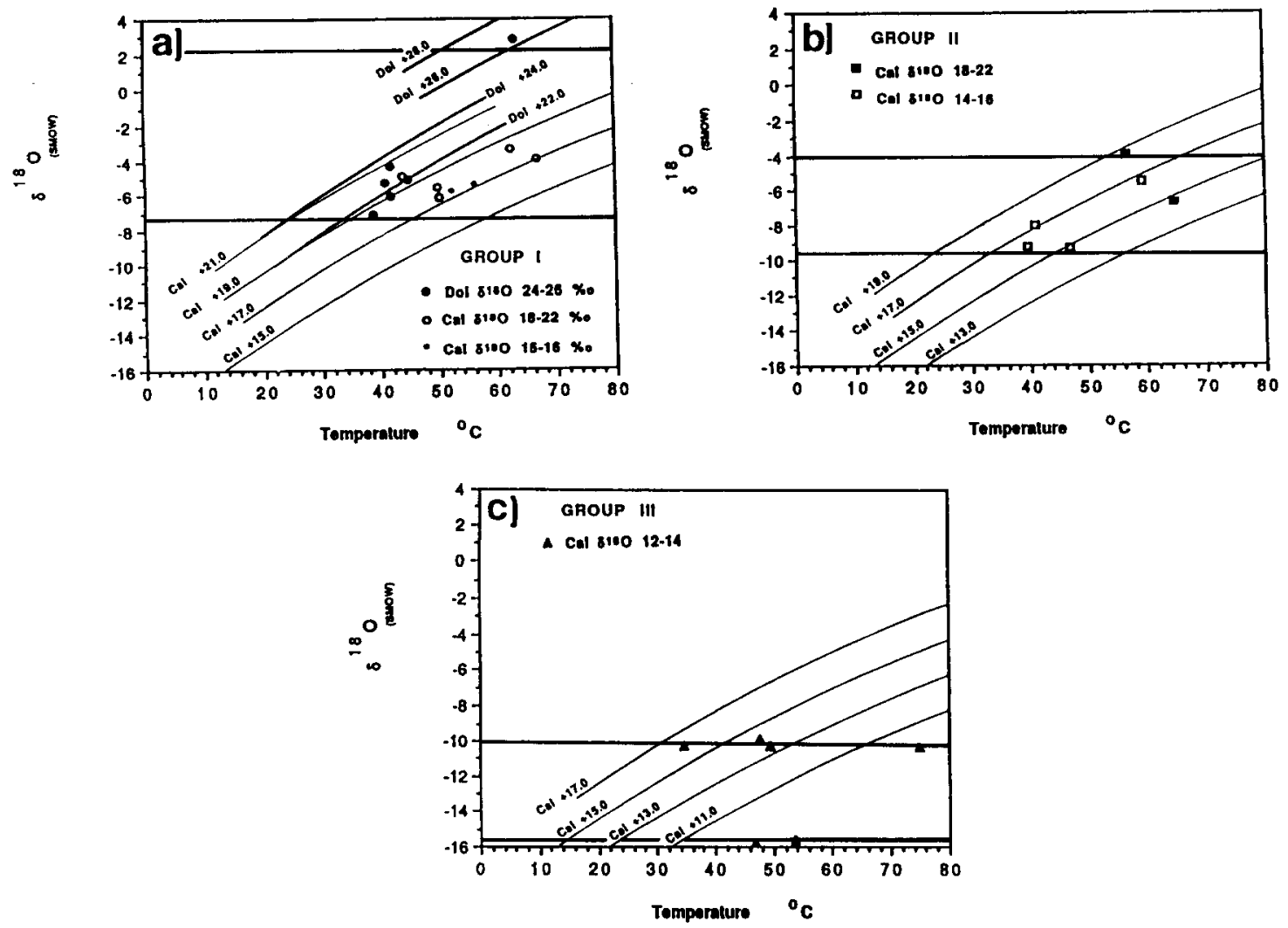

FIG. 3. Plot of isotope equilibrium between formation waters and carbonate in the Alberta Basin. (a) Group I: the large solid dots represent waters extracted from dolomite with $\delta^{18} \mathrm{O}=+25$ to $+30 \%$ (SMOw); the open dots represent waters in limestones with $\delta^{18} \mathrm{O}=+18$ to $+22 \%_{\text {(SMOW) }}$; the small dots represent calcite cements from clastic rocks with $\delta^{18} \mathrm{O}=+15$ to $+16 \%$ (SMOw). (b) Group II: solid squares represent waters extracted from whole rock limestone with $\delta^{18} \mathrm{O}=+18$ to $+22 \%$ (SMOW); calcite cements from sandstones with $\delta^{18} \mathrm{O}=+14$ to $+16 \%_{\text {(SMOw) }}$. (c) Group III: triangles represent waters extracted from rocks with authigenic calcites ranging from $\delta^{18} \mathrm{O}=+12$ to $+14 \%$ (SMOW). Line Dol 28 represents combinations of $\delta^{18} \mathrm{O}$ water and temperature in equilibrium with dolomite of $\delta^{18} \mathrm{O}=$ $+28 \%$ (SMOw). Similarly, line $\mathrm{Cal} 21$ represents combinations of $\delta^{18} \mathrm{O}$ water and temperature in equilibrium with calcite of $\delta^{18} \mathrm{O}=+21 \%$ (SMOW). The thicker lines represent the dolomite equilibrium relation with temperature and the thinner lines the calcite equilibrium relation. Horizontal lines on all three graphs depict the range in isotopic composition of the waters for the particular group illustrated. 
clastic, but contain reservoir waters from one carbonate unit (Jurassic). These waters are plotted in Fig. 3b. Most of the waters from this group have isotopic compositions which are in equilibrium or slightly enriched relative to the cement compositions. HitCHON and FRIEDMAN (1969) suggest that because extensive volumes of carbonate are only found at depth, enrichment of ${ }^{18} \mathrm{O}$ in the shallower formation waters probably results from exchange with carbonate cements or less likely, from exchange with $\mathrm{CO}_{3}^{-2}$ or $\mathrm{HCO}_{3}^{-}$in water. However, as in the case of the D isotopes, the $\delta^{18} \mathrm{O}$ signatures of our Group II waters are similar to those of Group I and thus are not consistent with separate sources of ${ }^{18} \mathrm{O}$. Furthermore, the carbonate cements in Group II reservoirs were predominantly formed subsequent to the pervasive influx of low- ${ }^{18} \mathrm{O}$ meteoric water after the Laramide Orogeny (LongSTAffe and Ayalon, 1987), indicating that water reactions with stratigraphically lower carbonate rocks may better explain the slight enrichments.

Waters from the low salinity clastic reservoirs of Group III are shown in Fig. 3c. Half of the waters are depleted in ${ }^{18} \mathrm{O}$ relative to equilibrium values, and half are near equilibrium with the authigenic calcite cements at present reservoir temperatures. Considered in the context of the tectonic history of the basin, data suggest that the low ${ }^{18} \mathrm{O}$ waters are largely influenced by local meteoric waters and have not reacted significantly with earlier formed calcite cements.

In summary, most of the waters in the Alberta Basin do not appear to be in isotopic equilibrium with the carbonate phases present in the reservoir in which they reside. Furthermore, the waters are not biased toward ${ }^{18} \mathrm{O}$ depletion or enrichment but exhibit both traits, suggesting some communication between the waters of different stratigraphic units. Enrichment relative to equilibrium values likely results from waters derived from stratigraphically lower carbonate rocks in the basin (Devonian carbonates); depletion relative to equilibrium is probably due to regional flushing of meteoric waters subsequent to the Laramide Orogeny. In addition, the data suggest that the waters are, or were in the recent past, actively moving in the basin. If not, a greater degree of equilibration would be observed, particularly with the carbonate phases which are generally more reactive than silicate minerals. Enriched isotopic values have been attributed to the effects of membrane filtration (HITCHON and FrIEDMAN, 1969); however, the chemical data (ConNolly et al., 1990) and shale abundance and composition in the Alberta Basin dispute this. Albitization is also unlikely to have been a significant influence on the isotopic composition of the waters, because carbonate phases are more abundant and more reactive than albite, and carbonate equilibration is not obvious. Furthermore, albitization is not a very significant process in the Alberta Basin (ConNolly, in prep.).
Relations with conservative chemical constituents. Although the data are not conclusive, extensive rock buffering of $\delta^{18} \mathrm{O}$ values in Alberta Basin waters is not apparent from equilibrium modeling presented above. Alternatively, $\mathrm{D}$ is less prone to diagenetic alteration. The $\delta \mathrm{D}$ values of formation waters plotted against geochemical constituents which largely behave conservatively $(\mathrm{Na}, \mathrm{Cl})$ is a useful technique to distinguish chemical variations in subsurface waters which might be due to mixing of subsurface brines, as opposed to those due to water-rock interactions. Formation waters and clay minerals are the basic reservoirs of $\mathbf{H}$ in a sedimentary basin. If the amount of $\mathrm{H}$ in clay minerals is large in a sedimentary basin relative to the amount of formation water, then the clay minerals may significantly affect the water $\delta \mathrm{D}$ values. However, the amount of exchangeable $\mathrm{H}$ in clay minerals, relative to water $\mathbf{H}$, is generally small. Furthermore, the effective water-rock ratio is also increased if formation waters mainly flow through aquifers (KNAUTH, 1988), which is likely the case in the Alberta Basin (MAJorowicz et al., 1985; ToTH, 1989). Therefore, $\delta \mathrm{D}$ is largely conservative and well suited for distinguishing chemical variations. The $\delta^{18} \mathrm{O}$ composition of a water is more ambiguous because it may be influenced by both water and rock reservoirs. However, when used in conjunction with $\delta \mathrm{D}$ data, $\delta^{18} \mathrm{O}$ values can be used to indicate the relative proportion of water-rock interaction.

Figure 4 illustrates a series of plots of $\mathrm{Cl}$ and $\mathrm{Na}$ vs $\delta \mathrm{D}$, and $\mathrm{Cl}$ and $\mathrm{Na}$ vs $\delta^{18} \mathrm{O}$. On both $\delta \mathrm{D}$ plots (Figs $4 \mathrm{a}$ and 4c) a good linear relation is observed; regression of the data results in $x$-intercepts similar to the $\delta \mathrm{D}$ value indicated on Fig. 2, with the $\mathrm{Cl}$ vs $\delta \mathrm{D}=$ $-118 \%_{(\text {SMOw) }}$ and the Na vs $\delta \mathrm{D}=-120 \%_{\text {(SMOW) }}$. Separation of the waters into the three groups recognized from chemistry alone (Connol ly et al., 1990) is very pronounced. Comparing Figs $4 a$ and $4 c$ with the $\delta^{18} \mathrm{O}$ vs $\delta \mathrm{D}$ plot (Fig. 2), a meteoric water influence can be logically inferred. Group I is the most saline and enriched in deuterium in Fig. 4, with some samples showing some deviation from the main cluster. Many of the Group I samples are from variable Devonian reefal facies (platform, pinnacle), with fluid movement differing in these two environments. The pinnacle reefs (Leduc Formation) direct pore waters from surrounding compacting shales upward through the reef resulting in vertical brine movement and permeability zoning (DAVIS, 1972), whereas fluid movement in the platform reefs have a more dominant lateral component. This variation may cause some of the scatter observed on the plot (Fig. 4). Group II waters have lower $\mathrm{Na}$ and $\mathrm{Cl}$ concentrations, but have similar $\delta \mathrm{D}$ values to Group I. Group III is by far the most dilute, with a significant gap separating it from Group I and II. Group III waters also have the lowest $\delta \mathrm{D}$ values; several samples have $\delta \mathrm{D}$ values very similar to present rainfall. 

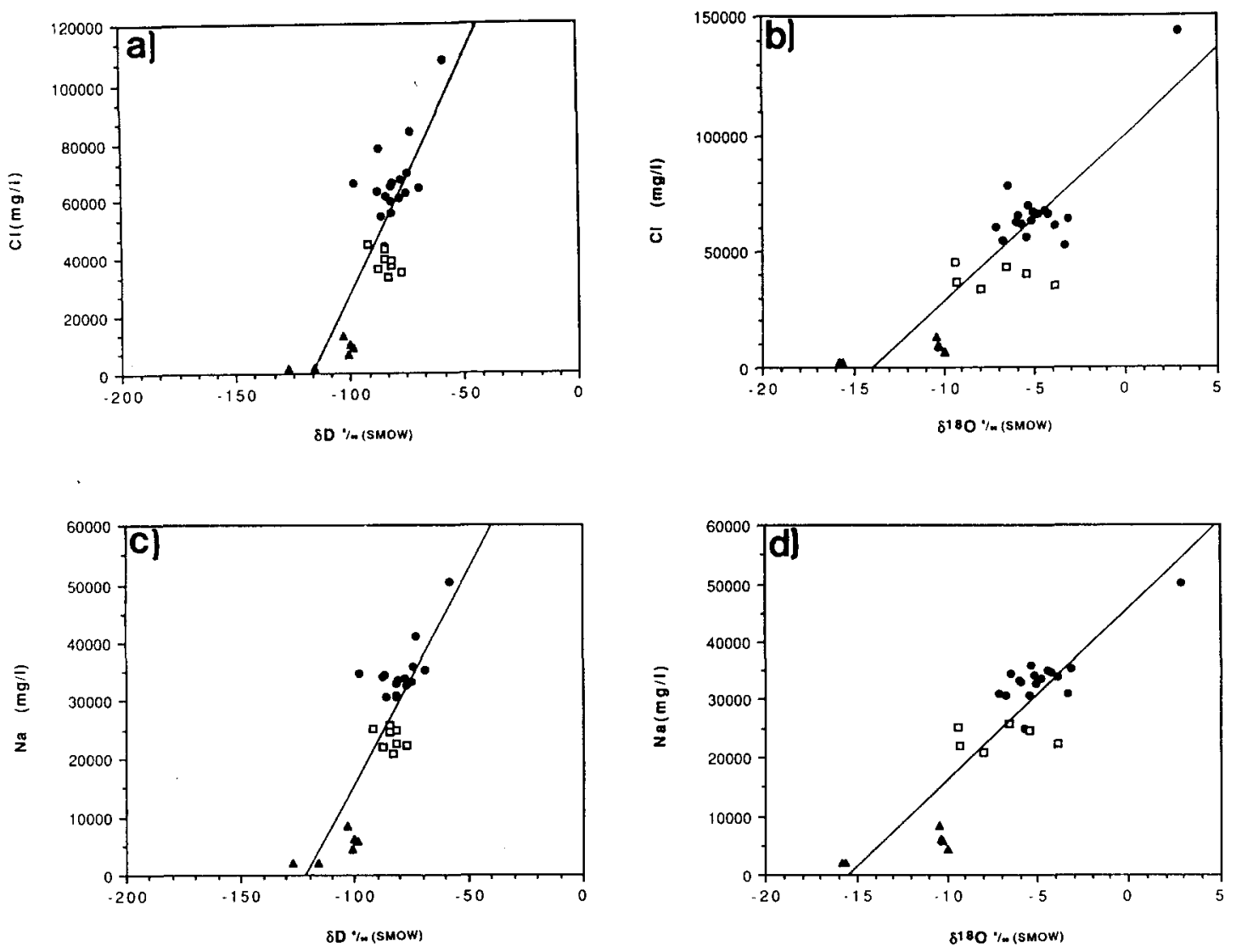

Fig. 4. (a) Cl vs $\delta \mathrm{D}_{\text {(Smow) }}$; (b) $\mathrm{Cl}$ vs $\delta^{18} \mathrm{O}_{\text {(SMow) }}$; (c) Na vs $\delta \mathrm{D}_{\text {(SMOw) }}$; and (d) $\mathrm{Na}$ vs $\delta^{18} \mathrm{O}_{\text {(Smow) }}$. A near linear correlation is observed in all of the plots; however, on all of the plots Group III appears detached from Groups I and II. These graphs are interpreted largely in terms of mixing. The scale of the plots were designed to encompass the range of isotopic values common in sedimentary basins. The correlation of each of the plots is better than $r=0.8$.

The $\mathrm{Na}$ and $\mathrm{Cl}$ vs $\delta^{18} \mathrm{O}$ graphs were plotted to assess the impact of water-rock interaction (Figs $4 \mathrm{~b}$ and $4 \mathrm{~d}$ ). The $x$-intercepts, determined by regression of the data, for both the $O$ graphs are notably less than on Fig. 2, with the $\mathrm{Cl}$ vs $\delta^{18} \mathrm{O}$ plot $=$ $-14 \%_{(\text {SMOW })}$ and the $\mathrm{Na}$ vs $\delta^{18} \mathrm{O}$ plot $=$ $-15.5 \%$ (SMOW). These values deviate from meteoric water values slightly more than the $\delta \mathrm{D}$ values, when the amount of error associated with the two analyses (i.e. $0.13 \%$ for $\delta^{18} \mathrm{O}$ and $2.3 \%$ for $\delta \mathrm{D}$ ) is considered. This is likely because of some $O$ isotope exchange between the water and rock, particularly the carbonate phases. Thus, Figs $4 \mathrm{~b}$ and $4 \mathrm{~d}$ corroborate the lack of ${ }^{18} \mathrm{O}$ equilibration in host carbonates (Fig. 3). Although processes such as albitization and $\mathrm{O}$ isotope exchange with carbonate minerals have likely occurred to some degree in the basin, they have not significantly affected the $\delta^{18} \mathrm{O}, \delta \mathrm{D}$ isotope systematics of the present formation waters.

Evaporated sea water component. If minimal water-rock interaction is indicated by the stable $\mathrm{O}$ and $\mathrm{H}$ isotopic composition of the waters in a sedimentary basin, mixing of evaporated brines with meteoric water can, in many cases, account for the isotopic composition of the formation waters (Knauth and Beeunas, 1986). Highly evaporated sea water can have negative $\delta$-values similar to some meteoric waters, given the hooked-shaped isotope trajectory of evaporated brines (Fig. 5; KNAUTH and BeEunas, 1986). Domenico and RobBins (1985) also show that meteoric waters do not completely flush out dense, residual brines, but rather mix with these brines. Such behavior will produce linear mixing trends on a $\delta \mathrm{D}-\delta^{18} \mathrm{O}$ diagram similar to those commonly observed (Clayton et al., 1966). In the Alberta Basin, the $\delta \mathrm{D}$ and $\delta^{18} \mathrm{O}$ values of formation water increase with increasing salinity, indicating a meteoric or mixed meteoric-marine origin. Because a residual sea water component associated with marine evaporite deposits is consistent with formation water chemistry (ConNolly et al., 1990) the possibility of a hooked-shaped sea water evaporation trajectory should be evaluated.

During sea water evaporation, residual waters at first become enriched in ${ }^{18} \mathrm{O}$ and $\mathrm{D}$, but then become depleted as evaporation proceeds, resulting in a hooked-shaped trajectory (Fig. 5). Two sea water evaporation trajectories are shown on Fig. 5: the curve of HOLSER (1979), which is based on laboratory 


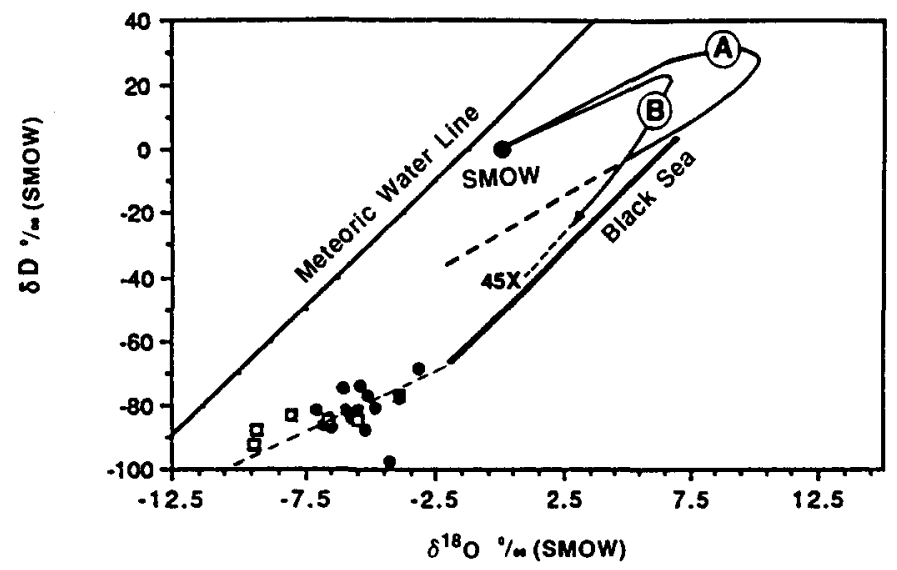

Fig. 5. Stable isotopic compositions of D and $\mathrm{O}$ in Group I and Group II formation waters with the trajectories for sea water undergoing evaporation superimposed on them. Curve $A$ is the estimate of HOLSER (1979) of evaporating sea water through a concentration of $10 \times$. Curve B is given by Pierre $e$ al. (1984) and is based on field evidence from the Ojo de Licbre waters. Halite facies corresponds to approximately $11 \times-65 \times$ (modified from KNAUTH and BEEUnAS, 1986). The thick black line represents the Black Sea trend after it has hooked around to a concentration of $80 \times$ (GUTSALO, 1980).

data; and the curve of PIERRE et al. (1984), which is based on the evaporation of the Ojo de Liebre waters. The curve proposed by PIERrE et al. (1984) closely approximates the evaporation curve of the Black Sea (Gutsalo, 1980), and both curves show a more rapid and pronounced decrease in $\delta \mathrm{D}$ than the curve of Holser (1979), for equivalent increases in concentration. Furthermore, the PIERre et al. (1984) curve closely parallels the meteoric water line after it recurves. This parallelism likely reflects conditions close to equilibrium which exist after the isotope evaporation curve hooks around when phase transitions in hydration spheres are occurring (Gutsalo, 1980).

Even the most saline Alberta Basin formation waters have very negative $\delta \mathrm{D}$ values. If an evaporite brine is an end-member, an extremely negative $\delta \mathrm{D}$ value is required to produce a mixing line between a brine and meteoric waters with the orientation of the trajectory for Alberta Basin formation waters on a $\delta \mathrm{D}$ vs $\delta^{18} \mathrm{O}$ plot (Fig. 5). Halite precipitation begins at $11 \times$ and continues to $65 \times$ evaporated concentration of sea water (CARPENTER, 1978). CONNOLLY et al. (1990) have shown that waters in Group I have experienced extensive evaporation and gone beyond halite precipitation. Their data indicate that the more concentrated waters could have evaporated to a concentration of $4545 \times$. However, extrapolation of the Pierre et al. (1984) curve to $45 \times$ concentration does not produce sufficiently negative $\delta \mathrm{D}$ values representative of the Alberta Basin waters. Measured $\delta \mathrm{D}$ values for the Black Sea (Gutsalo, 1980) are close to the curve of Pierre et al. (1984) and come close to a likely evaporite brine end member composition for the Alberta Basin formation waters. However, this $\delta$ D value for the Black Sea (Fig. 5) represents $80 \times$ concentration, which exceeds the field of halite precipitation and the degree of concentration likely experienced by Group I fluids.
Most likely, the isotopically heavy end member of the brine had a more complicated origin. One scenario would involve an evaporating brine subjected to intermittent incursions of meteoric water. The various marine incursions in the Devonian were separated by periods of uplift, during which the hydrodynamic situations allowed the influx of fresh water (Gorrell and Alderman, 1968). The influence of episodic meteoric recharge into an evaporated pan is shown in Fig. 6. Here, sea water evaporates along a positive slope toward point $\mathrm{A}$ and is subsequently subjected to mixing with meteoric water. This process drives the isotopic composition of the brine from point $\mathrm{A}$ downward back toward the MWL, with the amount of displacement depending on the relative proportions of the waters being mixed. During the Devonian the study area was progressively migrating toward higher latitudes and lower temperatures, so that recharging meteoric water would have had an increasingly negative stable isotopic composition. In addition, uplift to the west would have caused a decrease of the isotopic values of meteoric waters, due to altitudinal effects. The zigzag pattern on Fig. 6 depicts hypothetical incursions of progressively isotopically depleted waters into the basin. Although the exact path over which the water evolved is highly speculative, the end members, an evaporated sea water component (CONNOLLY et al. 1990) mixing with meteoric water, is reasonably well constrained and compatible with the tectonic history. Thus, the very negative $\delta$-values of Alberta Basin waters does not rule out an evaporated sea water component.

$\delta D$ Homogeneity between water groups. Previous arguments suggest that all of the rocks in the Alberta Basin have been affected by meteoric recharge, and that Group III waters are chemically and isotopically distinct from those of Group I and Group II. The 


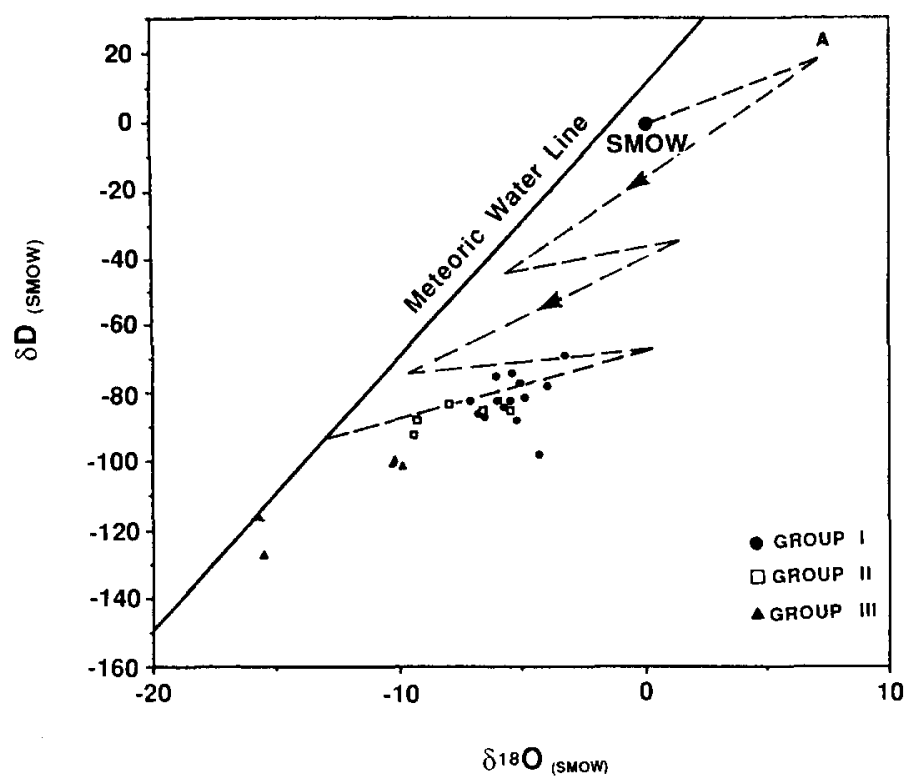

FiG. 6. Possible combination of evaporation-mixing steps to produce the observed isotopic compositions; arrows illustrate the direction in which the fluids are evolving.

waters in Group I and Group II have relatively constant $\delta \mathrm{D}$ values $(-82.2 \pm 6.3 \%$ o regardless of depth or stratigraphic unit; a regression line of the stable isotope results for these two groups intersects the MWL at $\delta \mathrm{D}=-96 \%_{\text {(SMOW) }}$ and $\delta^{18} \mathrm{O}=$ $-13.3 \%$ (SMOw). Importantly, these values are greater than modern rainfall $\delta \mathrm{D}$ and $\delta^{18} \mathrm{O}$ values by $25 \%$ and $3 \%$, respectively.

Group I and Group II waters have a large lateral and vertical extent over which $\delta \mathrm{D}$ values are consistent. The lack of significant variation in the $\delta \mathrm{D}$ values of waters from Group I and Group II (DevonianLower Cretaceous) and the fact that they differ from present meteoric values, both indicate minimal influence from the overlying flow subsystems which are flushed with modern meteoric waters. Garven (1989) has suggested that gravity driven flow in the Western Canada Sedimentary Basin, initiated by the Laramide Orogeny, was probably active until dissipation of the regional flow system in the MiocenePliocene.

To evaluate whether the Group I and Group II waters represent formations waters retained since the Neogene, conditions at that time must be examined. Paleolatitude studies indicate essentially the same latitude situation for western Canada during the postLaramide period (HITchon and Friedman, 1969); however, the mean annual temperature in the Neogene was approximately $9^{\circ} \mathrm{C}$ (WoLFE, 1980). This is at least $4^{\circ} \mathrm{C}$ warmer than the present average surface temperature of $5^{\circ} \mathrm{C}$ (Hitchon, 1984) for the study area. DANSGAARD (1964) has shown that current meteoric waters change in $\delta \mathrm{D}$ by $5.6 \%$ and $\delta^{18} \mathrm{O}$ by $0.7 \%$ for every $1{ }^{\circ} \mathrm{C}$ change in temperature. Deviations from these values due to kinetic effects such as altitude and lateral migration of weather inland across the continent should not have been any different than they are today. Topographic relief of the Rocky Mountains was at a maximum in early Eocene time (BEAUMONT, 1981; Hitchon, 1984), with uplift and erosion being the strongest during the Oligocene and Miocene. However, toward the end of the Miocene and in the Pliocene, the altitude of the Rocky Mountains was similar to the present day (BEAUMONT, 1981). The lateral distance of rain and weather eastward across Canada was also similar in the Pliocene to present day. Thus, the changes in $\delta \mathrm{D}$ and $\delta^{18} \mathrm{O}$ values for meteoric waters resulting solely from temperature may be applied in this situation. The Pleistocene glaciations were not considered to be a contributing influence to the isotopic composition of the Group I and Group II waters because these events occurred subsequent to dissipation of the regional flow regime (GARVEN, 1989).

Considering the temperature effect, $\delta \mathrm{D}$ and $\delta^{18} \mathrm{O}$ values of rain-water in the Neogene would have been higher by $22 \%$ and $2.8 \%$, respectively, relative to modern meteoric waters. Both values are similar to the differences noted above between the actual Group I and Group II intersection with the MWL and the present rainfall values. Therefore, the isotopic composition of Group I and Group II waters indicate that meteoric waters in the Pliocene are one end member of a two component mixing system, with an evaporated brine component being the other member. Hydrochemical isolation of Group I and Group II waters since the Neogene would be required to preserve the mixing relations. This isolation was likely a result of the dissipation of the regional flow system into local flow systems (GARVIN, 1989). 


\section{Sr isotopes}

General stratigraphic trends. The ${ }^{87} \mathrm{Sr} /{ }^{86} \mathrm{Sr}$ ratios for formation waters and diagenetic cements from the Alberta Basin are shown in Fig. 7 as a function of age of the reservoir rock (as opposed to the age of a given cement which could be much younger) relative to the Sr isotope age curve for sea water (BURKE et al., 1982). This curve reflects a balance between the input of $\mathrm{Sr}$ with low ${ }^{87} \mathrm{Sr} /{ }^{86} \mathrm{Sr}$ ratios from mid-ocean ridge basalts and of $\mathrm{Sr}$ with high ${ }^{87} \mathrm{Sr} /{ }^{86} \mathrm{Sr}$ ratios from continental erosion, for a given time period. Strontium has a long residence time in the ocean which therefore has a uniform $\mathrm{Sr}$ concentration and isotopic composition throughout the oceans at any given time. Thus, $\mathrm{Sr}$ is a useful indicator of the changes that occur in water chemistry during diagenesis of marine sediments.

Deviation of formation water ${ }^{87} \mathrm{Sr} /{ }^{86} \mathrm{Sr}$ ratios from the Burke curve indicates a contribution of $\mathrm{Sr}$ from sources other than sea water or marine minerals (carbonates or evaporites) in the host rock. Most of the waters are more radiogenic than coeval sea water values until the Upper Cretaceous. Waters extracted from Upper Cretaceous reservoirs have significantly less radiogenic signatures than Upper Cretaceous sea water. The large excursion in brine ${ }^{87} \mathrm{Sr} /{ }^{86} \mathrm{Sr}$ from the sea water age curve precludes a $\mathrm{Sr}$ source from sea water of any age and indicates water-rock interaction must have altered the formation water chemistry in the Alberta Basin.

All of the formation waters are more radiogenic

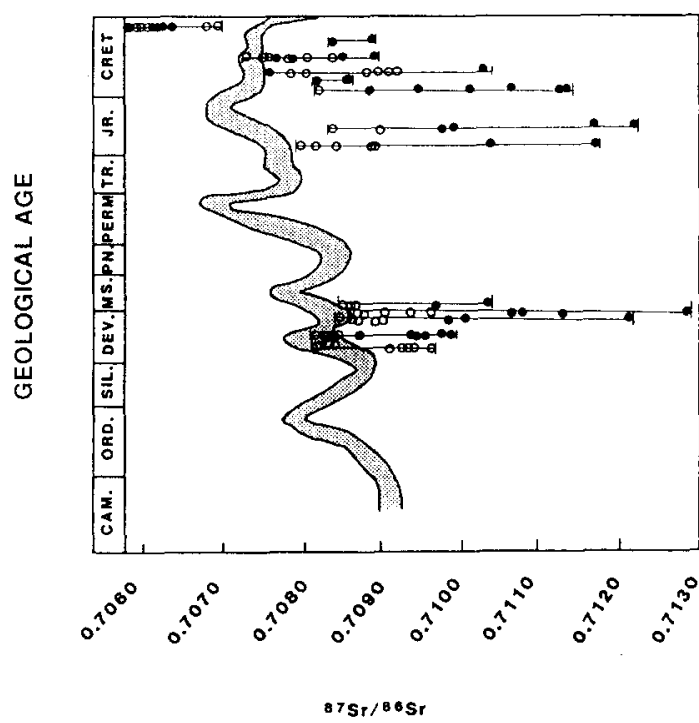

FIG. 7. Strontium isotopic composition of waters (O) and diagenetic calcites $(O)$ from the Alberta Basin. The sea water curve is from BURKE et al. (1982). Note that most of the rocks and waters are radiogenic with respect to sea water for the time in question except the Upper Cretaceous where waters and rocks become less radiogenic. All of the waters are more radiogenic than the rocks until the Upper Cretaceous when they start to overlap. than the corresponding diagenetic cements for a specific stratigraphic unit until the upper Lower Cretaceous to Upper Cretaceous reservoirs, when their values begin to overlap. The ${ }^{87} \mathrm{Sr} /{ }^{86} \mathrm{Sr}$ values for the waters and minerals in the oldest Devonian formation (Leduc) sampled are also reasonably close to each other. The general lack of comparable waterrock ${ }^{87} \mathrm{Sr} /{ }^{86} \mathrm{Sr}$ ratios indicates that the diagenetic carbonates were formed earlier in the burial history and that the water $\mathrm{Sr}$ isotopic composition subsequently evolved, with little $\mathrm{Sr}$ isotope reequilibration between the waters and the cements. This is consistent with some relatively rapid changes in basin configuration, hydrodynamics and geothermometry induced by the Laramide Orogeny.

Whole-rock and diagenetic fractions from all stratigraphic units in the study area have been analyzed for ${ }^{87} \mathrm{Sr} /{ }^{86} \mathrm{Sr}$, except for the Devonian shales (Table 2). The only stratigraphic units that have ${ }^{87} \mathrm{Sr} /{ }^{86} \mathrm{Sr}$ ratios greater than any of the formation waters are Cambrian shales and the Precambrian basement. Most of the other units in the stratigraphic column, particularly the shales (e.g. Poker Chip Shale), have ${ }^{87} \mathrm{Sr} /{ }^{86} \mathrm{Sr}$ ratios similar to the highest ${ }^{87} \mathrm{Sr} /{ }^{86} \mathrm{Sr}$ values from the waters. However, rock $\mathrm{Sr}$ ratios must be higher than those of the waters in order for the former to raise the latter $\mathrm{Sr}$ isotopic ratio. Strontium is more mobile during weathering than $\mathrm{Rb}$, and the ${ }^{87} \mathrm{Sr} /{ }^{86} \mathrm{Sr}$ ratio of the $\mathrm{Sr}$ that goes into solution is generally lower than the ${ }^{87} \mathrm{Sr} /{ }^{86} \mathrm{Sr}$ ratio of the rock (Stanley and Faure, 1979). Stueber et al. (1987) conducted leaching experiments on shales with whole-rock values of 0.75472 , where the leachate yielded values of only 0.71229 and 0.71178 , depending on the leaching reagent. It is apparent, then, that the clastic and carbonate rocks are in hydraulic communication because the ${ }^{87} \mathrm{Sr} /{ }^{86} \mathrm{Sr}$ ratios of some waters in the Jurassic and Lower Cretaceous contain highly radiogenic Sr. However, Devonian and/or Cambrian shales are the only apparent source for these more radiogenic $\mathrm{Sr}$ isotopic ratios.

There appears to be a discrepancy between the degree of water-rock interaction indicated by the stable $\mathrm{O}$ and $\mathrm{H}$, and the radiogenic $\mathrm{Sr}$ isotopic data. This may be explained by considering the differences in relative concentrations of $\mathrm{O}$ and $\mathrm{Sr}$ in water and solid phases. A large reservoir of $\mathrm{O}$ is present in both the rock and water phase, resulting in the $O$ isotopic composition of the water changing toward equilibration with the rock at relatively high water-rock ratios. However, owing to low $\mathrm{Sr}$ concentrations in waters relative to rocks, the $\mathrm{Sr}$ isotopic composition of the water is reset at a water-rock ratio an order of magnitude lower than that required to reset its $O$ isotopic composition (BANNER et al., 1989) and a variation in the apparent degree of equilibration occurs.

Mixing relations. The linear trends observed in the $\mathrm{Na}$ and $\mathrm{Cl}$ vs $\delta \mathrm{D}$ and $\delta^{18} \mathrm{O}$ plots (Fig. $4 \mathrm{a}-\mathrm{d}$ ) suggest 


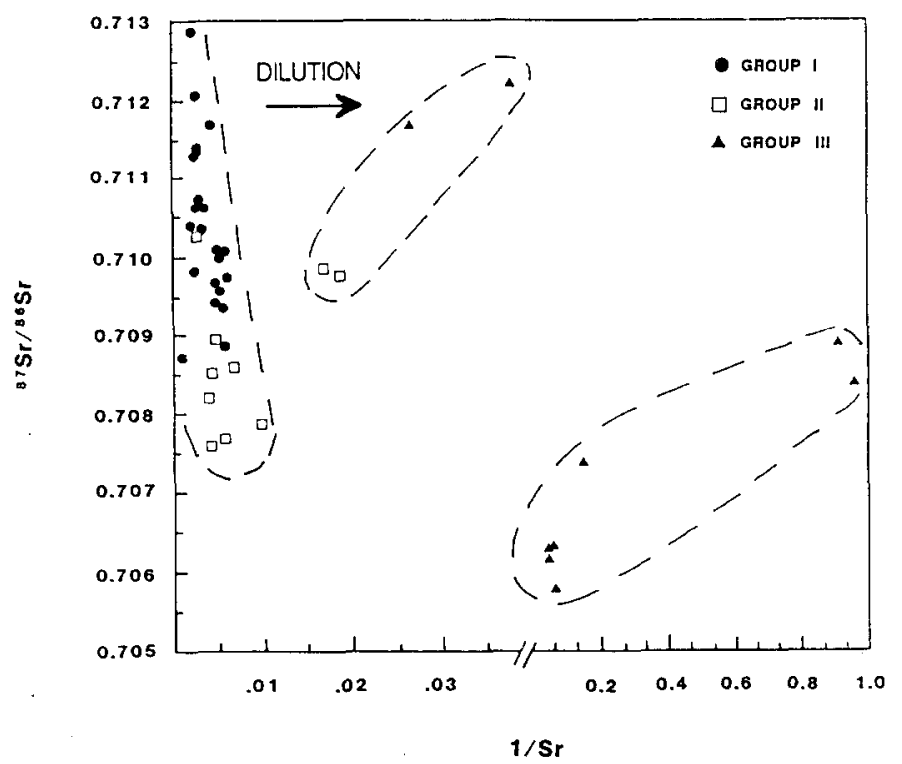

Fig. 8. $87 \mathrm{Sr} / 86 \mathrm{Sr}$ vs $1 / \mathrm{Sr}$ plot of Alberta Basin waters. The scale has been broken to accommodate the Cardium and Belly River water samples from Group III on the plot.

possible mixing relations between waters of the Alberta Basin, which may be best described by the processes of diffusional upward flow (HANOR, 1984) or density stratification (LAND, 1987). Linear relations observed for these waters on sea water evaporation curves and elemental plots (ConNolly et al., 1990) suggest that the waters in different stratigraphic units composing Group I and Group II are in contact with one another and are not behaving as isolated hydrological systems.

Potential mixing relations can be tested using a plot of ${ }^{87} \mathrm{Sr} /{ }^{86} \mathrm{Sr}$ ratios vs reciprocal Sr (Table 1). The goodness of fit of the data points to a straight line tests the strength of the mixing hypothesis and the assumption that the waters were not altered in some way after mixing (FAure, 1986). The plot of ${ }^{87} \mathrm{Sr} /{ }^{86} \mathrm{Sr}$ vs 1/Sr (Fig. 8) for all of the Alberta Basin formation waters displays several trends or groups. First, the extremely dilute samples from the Cardium and Belly River units in Group III are also extremely depleted in $\mathrm{Sr}$. As with other chemical components ( $\mathrm{CON}-$ NoLly et al., 1990), the Sr isotopic systematics of the Group III waters attest to their lack of association with the rest of the brines in the basin. Second, with the exception of several Group II brine samples, most Group I and II water samples form a nearvertical array with a slightly negative slope. The dominantly carbonate hosted brines of Group I generally have higher ${ }^{87} \mathrm{Sr} /{ }^{86} \mathrm{Sr}$ ratios than formation waters from the clastic rocks of Group II, but $\mathrm{Sr}$ concentrations of both groups are quite similar. This behavior is unusual because carbonate rocks generally have high average $\mathrm{Sr}$ concentrations (610 ppm; FAURE, 1986) and relatively low isotopic ratios $(0.708-0.709)$, whereas shales and sandstones have much lower average $\mathrm{Sr}$ concentrations (sandstone 20 ppm; shale $300 \mathrm{ppm}$; FaUre, 1986) and much higher ${ }^{87} \mathrm{Sr} /{ }^{86} \mathrm{Sr}$ ratios; these characteristics result in the positive slope usually observed on ${ }^{87} \mathrm{Sr} /{ }^{86} \mathrm{Sr}$ vs $1 / \mathrm{Sr}$ plots.

The contribution of $\mathrm{Sr}$ from the rock to the fluid phase is controlled by mineral reactivity and solubility, both of which tend to be greater for carbonates than for clastic rocks. Carbonate minerals, plagioclase and volcanic ash are important sources of $\mathrm{Sr}$. Clay, microcline, mica, apatite and ferromagnesium minerals contribute less $\mathrm{Sr}$, either because they are more resistant to chemical weathering, have low $\mathrm{Sr}$ concentrations, or both (STANLEY and FAURE, 1979).

When waters have interacted with rocks of two completely different lithological compositions, (c.g. carbonate and clastic rocks) and two completely different $\mathrm{Sr}$ concentrations and ${ }^{87} \mathrm{Sr} /{ }^{86} \mathrm{Sr}$ ratios, then two end member components can frequently be observed. In the Alberta Basin two different rock groups are present, the Paleozoic and Jurassic carbonates and the Cretaceous clastics. From previous discussions it has been determined that the waters from these units. Group I and Group II, are in communication; therefore, a two component mixing line is expected. However, Fig. 8 indicates that the clastic rocks have high $\mathrm{Sr}$ concentrations, similar to the carbonates, and that a vertical trend is generated rather than a mixing line with a definable slope. When Fig. 8 is enlarged, a non-random mixing trend becomes definable with a negative slope. This negative slope is unique; to date a mixing line with such an orientation has not been reported, although low ${ }^{87} \mathrm{Sr} /{ }^{86} \mathrm{Sr}$ values similar to those from the Alberta Basin have been reported in the San Joaquin Basin (Boles, pers. commun.).

The positive slope on the right side of Fig. 8 
between some Group II and Group III waters, represents waters sampled from the Rock Creek Formation and Middle Jurassic units. Both of these waters, particularly that from the Rock Creek, have been shown by stable isotopes and chemical concentrations to be diluted to variable degrees by meteoric waters. The Middle Jurassic was sampled reasonably close to the Rock Creek sampling locations and may be affected by downward flow from the Rock Creek unit. Both waters are displaced to the right because of dilution, which would affect their Sr concentration but not their ${ }^{87} \mathrm{Sr} /{ }^{86} \mathrm{Sr}$ ratios.

In summary, the waters in Groups I and II appear to be an open chemical system with each other, with the Group II waters in stratigraphically higher units having lower $\mathrm{Sr}$ concentrations than those from Group I. It would appear that diffusional flow has been an active process between the high ${ }^{87} \mathrm{Sr}{ }^{86} \mathrm{Sr}$, carbonate-hosted waters and the $10{ }^{87}{ }^{87} \mathrm{Sr} /{ }^{86} \mathrm{Sr}$ clastic-hosted waters; a tentative density stratification has been established. Density stratification is characterized by a regular increase in salinity commonly observed in sedimentary basins. Barring forced flow or hydrothermal convection, which are unlikely processes in the study area, basins become stratified in their salinity distribution until displaced by meteoric recharge. This corroborates the previous argument that waters from Group I and II have not experienced meteoric recharge since at least the Pliocene.

Provenance of clastic sedimentary rocks. The concentration of $\mathrm{Sr}$ in sandstones and waters may be directly proportional to the abundance of a given mineral phase. STANLEY and FAURE (1979) show that $88.5-98.5 \%$ of the $\mathrm{Sr}$ in authigenic cements from the High Plains sequence of Nebraska and Wyoming originated from sources having low ${ }^{87} \mathrm{Sr} /{ }^{86} \mathrm{Sr}$ ratios $(0.706-0.709)$. The concentration of $\mathrm{Sr}$ in the sandstone from this sequence is directly proportional to the abundance of plagioclase, suggesting it is the principal source of the fluid $\mathrm{Sr}$ and the controls on the fluid ${ }^{87} \mathrm{Sr} /{ }^{86} \mathrm{Sr}$ ratio. This study emphasized the dominance of plagioclase and volcanic ash, both of which are characterized by low ${ }^{87} \mathrm{Sr} /{ }^{86} \mathrm{Sr}$ ratios, as prevalent sources of $\mathrm{Sr}$ dissolved in pore waters.

Petrographic analysis of rocks in the study area indicates that igneous and sedimentary terrains have contributed detritus to the Lower Cretaceous formations, with minor contributions from metamorphic sources. Previous studies dealing with Cretaceous rocks in the Alberta Basin have suggested that the sediment source was the Precambrian Shield to the east (CAMERoN, 1965; OrR et al., 1977), the Canadian Cordillera to the west (Mellon, 1967; Vigrass, 1977), or a combination of these two. In contrast, Putnam (1982) and Sutrner (1969) have suggested a more southerly source of sediment for the basin.

Toward the end of the Early Cretaceous, the regional dip of the Alberta Basin was to the north or northwest because of the rising mountain chain to the southwest. The Cretaceous river systems were draining toward the north (Fig. 9) (Williams and StelCK, 1975; Putnam, 1982). This inferred stream orientation and flow direction contrasts with sediment dispersal patterns previously proposed for the upper Lower Cretaceous in the study area. The distribution of sediments has been interpreted as having emanated eastward from the Canadian Cordillera in response to mountain building triggered by the Columbian Orogeny (Eisbacher et al., 1974; Miall, 1978). However, EISBACHER et al. (1974) also inferred a northward paleoflow direction subparallel to the mountain front. This theory eliminated high ${ }^{87} \mathrm{Sr} /{ }^{86} \mathrm{Sr}$ constituents from the Canadian Shield as a major source of detritus to the Alberta Basin during Cretaceous time and pointed to the northwest U.S.A. as a likely source of sediment.

The Rocky Mountains of western Montana and Idaho, which were either present or forming during Early Cretaceous (Putnam, 1982; Garven, 1989), are the main highlands to the southwest of the study area. Associated with these units was an eastward migrating volcanic regime. This volcanic belt was associated with regional orogenesis which originated in Oregon during the Middle to Late Jurassic and migrated as far east as western Montana during the Late Cretaceous and Early Tertiary. Culmination of this period of continuous mobility occurred in westcentral Montana with the onset of Laramide tectonism. Thus, the decrease in ${ }^{87} \mathrm{Sr} /{ }^{86} \mathrm{Sr}$ of both rocks and waters of the study area throughout the Cretaceous may be accounted for by the increasing influence of volcanic sediments, as the locus of deposition moved closer to the Alberta Basin in response to the migration of orogenic movements. Plagioclase and volcanic ash are dominant constituents of these volcanics, both of which could have contributed considerable Sr to the water, regardless of the fact that they were likely the most dominant mineral constitu-

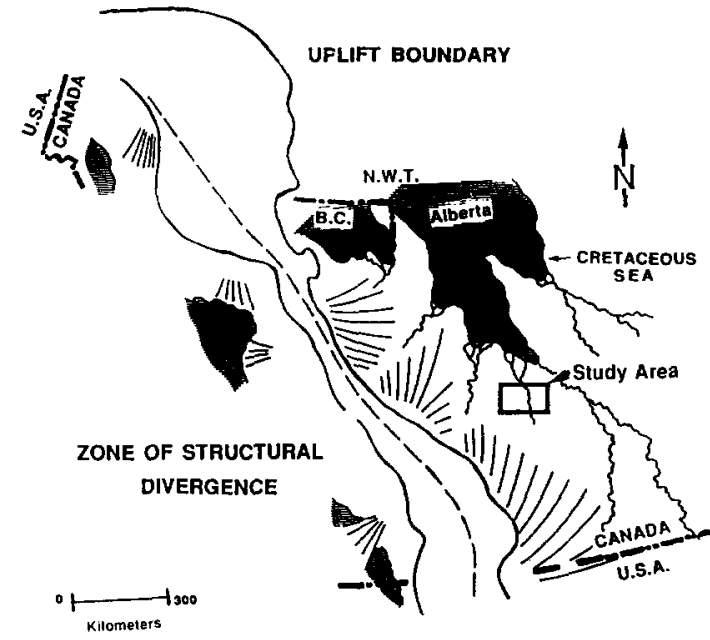

FIG. 9. Paleotectonic map of the Upper Mannville showing paleodrainage relative to the axis of the Columbian Orogeny (modified from EISBACHER et al., 1974). 
ents present. The ${ }^{87} \mathrm{Sr} /{ }^{86} \mathrm{Sr}$ ratios of volcanic rocks in continental environments tend to range from $0.703-$ 0.708 with a mean of 0.70577 (FAURE, 1986). Detritus from these volcanic rocks, plus ${ }^{87} \mathrm{Sr}$-poor sedimentary rocks from the same region, may be the origin of the low and decreasing ${ }^{87} \mathrm{Sr} /{ }^{86} \mathrm{Sr}$ ratios in the waters, particularly if these solids provide $>80 \%$ of the $\mathrm{Sr}$ to the waters, as is the case in other basins (STANLEY and FAUre, 1979).

A volcanic contribution to the Cretaceous sediments would help to explain the negatively sloped mixing trend observed between the dominantly carbonate (Group I) and clastic rocks (Group II) (Fig. 8 ). Volcanic rocks have an average $\mathrm{Sr}$ concentration of $465 \mathrm{ppm}$ (FAURE, 1986) which is quite similar to the average carbonate concentration of $610 \mathrm{ppm}$ for carbonates. If the former minerals release slightly less $\mathrm{Sr}$ than the latter, with different ${ }^{87} \mathrm{Sr} /{ }^{86} \mathrm{Sr}$ ratios, the negative slope in Fig. 8 could result.

\section{CONCLUSIONS}

Formation waters in the Alberta Basin form three hydrochemical groups: (1) Group I is composed of waters from the Devonian and Mississippian carbonates and the Cretaceous Basal Quartz Formation; (2) Group II is composed of waters from Cretaceous clastic rocks of the Ostracod, Glauconitic and Viking Formations, together with the Jurassic waters; (3) Group III is composed of waters from the Belly River, Cardium and Rock Creek stratigraphic units.

Plots of stable isotopes ( $\delta \mathrm{D}$ vs $\left.\delta^{18} \mathrm{O}\right)$, combined stable isotope and elemental data $(\mathrm{Cl}$ vs $\delta \mathrm{D} ; \mathrm{Cl}$ vs $\left.\delta^{18} \mathrm{O}\right)$ and ${ }^{87} \mathrm{Sr} /{ }^{86} \mathrm{Sr}$ vs $1 / \mathrm{Sr}$, suggest that two hydrological regimes are present in the basin. One regime is dominated by flushing of modern meteoric waters through the upper portion of the sedimentary succession and is represented by Group III waters. The second regime is isolated from the first and is characterized by association between Group I and II waters. This regime is composed of a mixture of meteoric waters that flushed through the basin as a result of Laramide tectonism and original connate brines. Group I and II formation waters became isolated from present day meteoric water recharge during the Pliocene; upward diffusional flow and density stratification followed, resulting in stratigraphically lower formations becoming more saline than the formations located stratigraphically higher in the section.

Variation in water ${ }^{87} \mathrm{Sr} /{ }^{86} \mathrm{Sr}$ ratios indicate that different types of water-rock interactions and changes in provenance have occurred in the basin. The ${ }^{87} \mathrm{Sr} /{ }^{86} \mathrm{Sr}$ ratios in Group I waters $(0.7076-$ 0.7129 ) are strongly influenced by Devonian and Cambrian shales. The ${ }^{87} \mathrm{Sr} /{ }^{86} \mathrm{Sr}$ ratios for waters and diagenetic minerals in the upper Lower and Upper Cretaceous yield low values $(0.7058)$ suggesting that a volcanic source to the southwest (Montana) was a significant source of detritus.
Acknowledgements-We are very grateful to Karlis Muehlenbachs for making his laboratory available to us and for many helpful discussions. Bruce Keffer provided field assistance and graciously donated time in the laboratory. The investigation and manuscript benefitted from discussions with Dave Sassani, Everett Shock, and Alan Stueber. We appreciate the patience and technical assistance of Ted Huston, Jim Steer, Elisabeth Toth, Diane Caird, and Marlene Scott. The paper was significantly improved by the careful reviews of two reviewers.

We would like to thank the following companies for permission to sample: ESSO Resources Canada (Dave Todd, Chris Ford); Gulf Resources Canada (Ron Mader); Enron Oil Canada Limited (Tim McKay); Prophet Petroleum (Andy Graw); Columbia Gas Development of Canada (Ray Kashmir); Westhill Resources (John Rodgers); Cabre Exploration (Gary Mascant); and Wellore Resources (Ron Savage). Financial support was provided by NSF grant EAR-8657180 (to L. M. Walter); NSERC post-graduate scholarship (to C. Connolly); and, Texaco Resources Canada Grant (to C. Connolly and F. J. Longstaffe) and NSERC operating grants A7387 (FJL) and OGP1168 (HB)

Editorial handling: Brian Hitchon.

\section{REFERENCES}

Banner J. L., Wasserburg G. J., Dobson P. F., Carpenter A. B. and Moore C. H. (1989) Isotopic and trace element constraints on the origin and evolution of saline groundwater from central Missouri. Geochim cosmochim. Acta 53, 383-398.

Beaumont C. (1981) Foreland basins. Geophys. J. Roy. Astro. Soc. 65, 291-329.

Billings G. K., Hitchon B. and Shaw D. R. (1969) Geochemistry and origin of formation waters in the western Canada sedimentary basin. 2. Alkali metals. Chem. Geol. 4, 211-223.

Burke W. H., Denison R. E., Hetherington E. A., Koepnick R. B., Nelson H. F. and Otro J. B. (1982) Variation of sea water ${ }^{87} \mathrm{Sr} /{ }^{86} \mathrm{Sr}$ throughout Phanerozoic time. Geology 10, 516-519.

Cameron E. M. (1965) Application of geochemistry to stratigraphic problems in Lower Cretaceous of western Canada. Am. Assoc. Petrol. Geol. Bull. 49, 62-80.

Carpenter A. B. (1978) Origin and chemical evolution of brines in sedimentary basins. Oklahoma Geol. Surv. Circ. 79, 60-77.

Chaudhuri S. (1978) Strontium isotopic composition of several oilfield brines from Kansas and Colorado. Geochim. cosmochim. Acta 42, 329-331.

Clayton R. N., Friedman I., Graf D. L., Mayeda T. K., Meents W. F. and Shimp N. F. (1966) The origin of saline formation waters, I. Isotopic composition. J. geophys. Res. 71, 3869-3882.

Coleman M. L., Shepherd T. J., Durham J. J., Rouse J. E. and Moore G. R. (1982) Reduction of water with zinc for hydrogen isotope analysis. Anal. Chem. 54, 993-995.

Connolly C. A., Walter L. M., BaAdsgaard H. and LONGSTAFFE F. J. (1990) Origin and evolution of formation waters, Alberta Basin, Western Canada Sedimentary Basin. I. Chemistry. Appl. Geochem. 5, 375-395.

CraIG H. (1961) Isotopic variations in meteoric waters. Science 133, 1702-1703.

DANSGAARD W. (1964) Stable isotopes in precipitation. Tellus 16, 436-468.

DAvis T. L. (1972) Velocity variations around Leduc Reefs, Alberta. Geophysics 17, 548-604.

Domenico P. A. and Robrins G. A. (1985) The displace- 
ment of connate waters from aquifers. Bull. Geol. Soc. Am. 96, 328-335.

Eisbacher G. H., Carrigy M. A. and Campbell R. B. (1974) Paleodrainage pattern and late orogenic basins of the Canadian Cordillera. In Tectonics and Sedimentation (ed. W. R. Dickinson), pp. 143-146. SEPM Spec. Pub. 22.

Epstein S., Graf D. L. and Degens E. T. (1964) Oxygen isotope studies on the origin of dolomite. In Isotopic and Cosmic Chemistry (eds H. Craig et al.), pp. 169-180. North Holland Publishing Company.

EPSTEIN S. and MAYEDA T. (1953) Variation of O-18 content of waters from natural sources. Geochim. cosmochim. Acta 4, 89-103.

Faure G. (1986) Principles of Isotope Geology (2nd Edn). John Wiley.

Friedman I. and O'NeIL J. R. (1977) Compilation of stable isotope fractionation factors of geochemical interest. In Data of Geochemistry. 6th Edn (ed. M. FletChER), U. S. Geol. Surv. Prof. Paper 440-KK.

Garven G. (1985) The role of regional fluid flow in the genesis of Pine Point deposit. Econ. Geol. 80, 307-324.

GARVEN G. (1989) A hydrogeologic model for the formation of giant oil sands deposits of the western Canada sedimentary basin. Am. J. Sci. 289, 105-166.

Gorrell H. A and Alderman G. R. (1968) Elk Point Group saline basins of Alberta, Saskatchewan. and Manitoba. Canada. Geol. Soc. Am. Spec. Paper 88, 291-317.

Graf D. L., Meents W. F., Friedman 1. and Shimp N. F. (1966) The origin of saline formation waters-III. Calcium chloride waters. Illinois State Geol. Surv. Circ. 393.

Gutsalo L. K. (1980) Trends and factors governing isotope shifts in evaporating brines and the criteria for underground brine production. Geokhimiya 11, 1734-1744.

HANOR J. S. (1984) Variation in the chemical composition of oil-field brines with depth in northern Louisiana and southern Arkansas: implication for mechanisms and rates of mass transport and diagenetic reaction. Gulf Coast Assoc. Geol. Trans. 34, 55-61.

Hitchon B. (1969a) Fluid flow in the Western Canada Sedimentary Basin, 1. Effect of topography. Water Resour. Res. 5, 186-195.

Hitchon B. (1969b) Fluid flow in the Western Canada Sedimentary Basin, 2. Effect of geology. Water Resour. Res. 5, 460-469.

Нrтснол B. (1984) Geothermal gradients, hydrodynamics, and hydrocarbon occurrence, Alberta, Canada. Am. Assoc. Petrol. Geol. Bull. 68, 713-743.

Hitchon B., Billings G. K. and Klovan J. E. (1971) Geochemistry and origin of formation waters in the western Canada sedimentary basin, III. Factors controlling chemical composition. Geochim. cosmochim. Acta 35, 567-598

Hurchon B. and Friedman 1. (1969) Geochemistry and origin of formation waters in the western Canada sedimentary basin. 1. Stable isotopes of hydrogen and oxygen. Geochim cosmochim. Acta 33, 1321-1349.

Holser W. (1979) Trace elements and isotopes in evaporites. In Marine Minerals (ed. R. G. BunNs), pp. 246-295. Reviews in Mineralogy, Mineral. Soc. Am.

Horita J. and Gat J. R. (1989) Deuterium in the Dead Sea: remeasurement and implications for the isotopic activity correction in brines. Geochim. cosmochim. Acta 53, 131133.

Kharaka Y. K. Berry F. A. and Friedman I. (1973) Isotopic composition of oil field brines from Kettleman North Dome oil field, California, and their geologica implications. Geochim. cosmochim. Acta 37, 1899-1908.

KNAUTH L. P. (1988) Origin and mixing history of brines, Palo Duro Basin, Texas, U.S.A. Appl. Geochem. 3, 455474.

Knauth L. P. and Beeunas M. A. (1986) Isotope geochemistry of fluid inclusions in Permian halite with implications for the isotopic history of ocean water and the origin of saline formation waters. Geochim. cosmochim. Acta $\mathbf{5 0}$, 419-433

LAND L. S. (1987) The major ion chemistry in sedimentary basins. In 2nd International Symposium on Physics and Chemistry of Porous Media, 160-179.

LANd L. S. and Prezbindowski D. R. (1981) The origin and evolution of saline formation water. Lower Cretaceous carbonates, south-central Texas, U.S.A. J. Hydrol. 54, 51-74.

Longstaffe F. J. and Ayalon A. (1987) Oxygen-isotope studies of clastic diagenesis in the Lower Cretaceous Viking Formation, Alberta: implications for the rolc of meteoric water. In Diagenesis of Sedimentary Sequences (cd. J. D. Marshall), pp. 277-296. Geol. Soc. Spec. Pub. 36.

Majorowicz J. A., Rahman M., Jones F. W. and McMilLAN N. J. (1985) The paleogeothermal and present thermal regimes of the Alberta Basin and their significance for petroleum occurrences. Bull. Can. Petrol. Geol. $\mathbf{3 3}$, 12-21.

Matthews A. and Katz A. (1977) Oxygen isotope fractionation during dolomitization of calcium carbonate. Geochim. cosmochim. Acta 41, 1431-1438.

MCCREA J. M. (1950) On the isotopic chemistry of carbonates and a palcotemperature scale. J. Chem. Phys. 18 849-857.

McNutt R. H., Frape S. K. and Dollar P. (1987) The strontium, oxygen and hydrogen isotopic composition of brines, Michigan and Appalachian basins, U.S.A. Appl. Geochem. 2, 495-505.

MCNutT R. H., FraPe S. K. and Fritz P. (1984) Strontium isotopic composition of some brines from the Precambrian Shield of Canada. Isotop. Geosci. 2, 205-215.

Mellon G. B. (1967) Stratigraphy and petrology of the Lower Cretaceous Blairmore and Mannville Groups, Alberta foothills and plains. Research Council Alberta Bull. 21, 1-270.

Miall A. D. (1978) Tectonic setting and syndepositional deformation of molasse and other nonmarine-paralic sedimentary basins. Can. J. Earth Sci. 15, 1613-1632.

OrR R. D. Johnston J. R. and Manko E. M. (1977) Lower Cretaceous geology and heavy oil potential of the Lloydminister area. Bull. Can. Petrol. Geol. 25, 1187-1221

Pierre C., Ortueb L. and Person A. (1984) Supratidal evaporitic dolomite at Ojo de Liebre lagoon: mineralogical and isotopic arguments for primary crystallization. $J$. Sediment. Petrol. 54, 1049-1061.

Posey H. H., Workman A. L. . Hanor J. S. and Hurst S. D (1985) Isotopic characteristics of brines from three oil and gas fields, southern Louisiana. Gulf Coast Assoc. Geol. Soc. Trans. 35, 261-267.

Putnam P. E. (1982) Fluvial channel sandstones within Upper Mannville (Albian) of Lloydminister area, Canada-geometry, petrography, and paleogeographic implications. Am. Assoc. Petrol. Geol. Bull. 66 436-459.

Russell C. W. and Cowart J. B. (1985) Strontium isotopc geochemistry of oil-field waters in southeastern Mississippi: evidence for fluid rock interaction and application as a hydrologic tracer. Geol. Soc. Am. Abstract with Programs 17, 705.

SOFER Z and GAT J. R. (1972) Activities and concentrations of oxygen-18 in concentrated aqueous salt solutions: analytical and geophysical implications. Earth Planet. Sci. Lett. 15. 232-238.

Stanley K. O. and Faure G. (1979) Isotopic composition and sources of strontium in sandstone cements: the High Plains Sequence of Wyoming and Nebraska. J. Sediment Petrol. 49, 45-54.

Starinsky A., Bielski M. , Lazar B., Steinitz G. and RaAB M. (1983) Strontium isotope evidence on the history of 
oilfield brines, Mediterranean Coastal Plain, Israel. Geochim. cosmochim. Acta 47, 687-695.

Stueber A. M., Pushkar P. and Hetherington E. A. (1984) A strontium isotopic study of Smackover brines and associated solids, southern Arkansas. Geochim. cosmochim. Acta 48, 1637-1649.

Stueber A. M., Pushkar P. and Hetherington E. A. (1987) A strontium isotopic study of formation waters from the Illinois basin. U.S.A. Appl. Geochem. 2, 477494.

Sunwall M. T. and Pushkar P. (1979) The isotopic composition of strontium in brines from petroleum fields of southeastern Ohio. Chem. Geol. 24, 189-197.

SUTTNER L. J. (1969) Stratigraphic and petrologic analysis of Upper Jurassic-Lower Cretaceous Morrison and Kootenai Formations, southwest Montana. Am. Assoc. Petrol. Geol. Bull. 53, 1391-1410.

Tотн J. (1989) Large-scale characteristics of pore-fluid potential fields in the Alberta Basin, Canada. EOS Trans., Am. Geophys. Union 70, 1096.

Vigras L. W. (1977) Trapping of oil at intra-Mannville (Lower Cretaceous) disconformity in Lloydminister area, Alberta and Saskatchewan. Am. Assoc. Petrol. Geol. Bull. 61, 1010-1028.

Walters L. J., JR., Claypool. G. E. and Choquette P. W. (1972) Reaction rates and $\delta^{18} O$ variation for the carbonate-phosphoric acid preparation method. Geochim. cosmochim. Acta 36, 129-140.

Williams G. D. and Stelck C. R. (1975) Speculations on the Cretaceous paleogeography of North America. In The Cretaceous System in the Western Interior of North America (ed. W. G. Caldwell), pp. 1-20. Geol. Assoc. Can. Special Paper 13.

Wolfe J. A. (1980) Tertiary climates and floristic relations at high latitudes in the northern hemispherc. Palaeogeogr. Palaeoclimatol. Palaeoecol. 30, 313-323. 